\title{
The extent and correlates of community-based pharmaceutical opioid utilisation
} in Australia

\author{
Louisa Degenhardt, Natasa Gisev, Elena Cama, Suzanne Nielsen, Briony Larance and \\ Raimondo Bruno
}

Running head: Pharmaceutical opioid use in Australia

1. National Drug and Alcohol Research Centre, UNSW, Australia

2. School of Medicine, University of Tasmania, Australia

Corresponding author: Louisa Degenhardt,

National Drug and Alcohol Research Centre, UNSW Australia, Sydney NSW 2052 AUSTRALIA

Phone: +61 29385 0333; Fax: +61 29385 0222; Email: I.degenhardt@unsw.edu.au

Key words: analgesics, opioids, prescribing, drug utilisation

Take home messages:

- There has been considerable concern regarding the increasing use of pharmaceutical opioids for pain and their potential to cause harm.

- This is particularly of concern in rural and regional areas, where there appears to be increasing problems related to opioid misuse, but almost no epidemiological research on utilisation.

- We provide an overview of pharmaceutical opioid utilisation across Australia, and consider socio-demographic factors that may affect utilisation levels.

- We present 2013 Australian pharmaceutical opioid sales data to community pharmacies by opioid type (buprenorphine, over-the-counter and prescribed codeine, dextropropoxyphene, fentanyl, hydromorphone, methadone, morphine, oxycodone, tapentadol and tramadol).

- In 2013, an estimated 10,747 kg (measured in oral morphine equivalents [OME]) of pharmaceutical opioids were utilised across Australia, equating to 481 OME mg per person over the year.

- There was considerable geographic variation in opioid utilisation, with higher rates of opioid utilisation (OME mg per person) in rural and regional areas. Geographic areas that were less populated, had more males and older people, proportionally more low income earning households and greater proportions in jobs requiring physical labour had higher utilisation rates.

Funding: LD, BL, SN and NG are supported by NHMRC research fellowships (\#1041472, \#1073858, \#1013803, \#1091878). The National Drug and Alcohol Research Centre at UNSW is supported by funding from the Australian Government under the Substance Misuse Prevention and Service Improvements Grant Fund.

Conflict of interest: SN, BL, RB and LD have received untied educational grants from Reckitt Benckiser for post-marketing surveillance of buprenorphine-naloxone tablets and film in the treatment of opioid dependence in Australia, development of an opioid-related behaviour scale, and/or a study examining opioid substitution therapy among chronic non-cancer pain This is the author manuscript accepted for publication and has undergone full peer review but has not been through the copyediting, typesetting, pagination and proofreading process, which may lead to differences between this version and the Version of Record. Please cite this article as doi: $10.1002 /$ pds.3931

This article is protected by copyright. All rights reserved. 
patients. RB, BL and $L D$ have received untied educational grant funding from Mundipharma for post-marketing surveillance of Reformulated OxyContin ${ }^{\circledR}$ in Australia.

This paper has not been published previously.

Word count: 2,743 word (text only)

\section{Abstract}

Purpose: There has been concern regarding increasing use of opioids and related harm. We present data on opioid utilisation across Australia, and consider socio-demographic factors that may affect utilisation rates.

Methods: IMS Health national sales data for over-the-counter (codeine) and prescription opioids (buprenorphine, codeine, dextropropoxyphene, fentanyl, hydromorphone, methadone, morphine, oxycodone, tapentadol and tramadol) were used to estimate total utilisation rates in the community during 2013, mapped to Statistical Local Areas (SLAs) and Remoteness Areas (RAs). All opioid amounts were measured in pack sales and milligrams, then converted to oral morphine equivalent milligrams (OME $\mathrm{mg}$ ) for comparison across opioids. Data on the demographic characteristics of SLAs were obtained from the ABS (sex and age distribution, income, and levels of physical labour) and other sources (number of pharmacies in SLAs), and were included in linear regression analyses.

Results: In 2013, an estimated 10,747 kg (OME) of opioids were sold across Australia, equating to 481 OME mg per person. There was considerable geographic variation in opioid utilisation, with higher rates of use in rural and regional areas. Geographic areas that were less populated, had more males and older people, proportionally more low-income earning households and greater proportions in jobs requiring physical labour, had higher utilisation rates.

Conclusions: Substantial geographic variation in opioid utilisation was identified, with areas outside of major cities having higher rates of utilisation of all types of opioids. Prescription monitoring and best practice interventions aimed at improving opioid use need to have a particular focus on areas outside of major cities.

This article is protected by copyright. All rights reserved. 


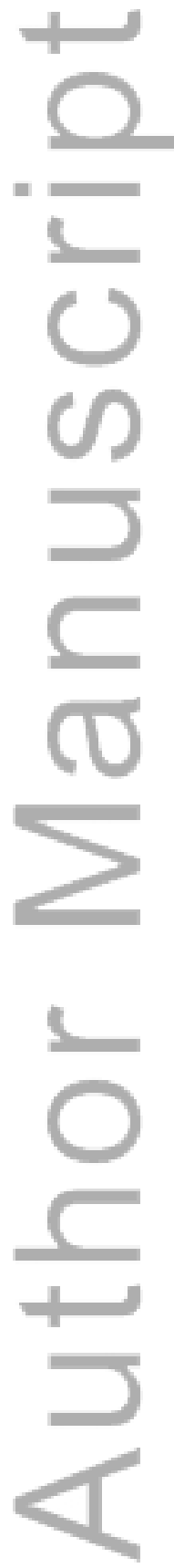

This article is protected by copyright. All rights reserved. 


\section{Introduction}

Pharmaceutical opioids are increasingly used for the treatment of chronic non-cancer pain, with a considerable rise in the use of these medicines in multiple countries. ${ }^{1,2}$ The increasing utilisation of pharmaceutical opioids has been met with concern regarding the potential for parallel increases in the non-medical use of these medicines, given the contribution to morbidity and mortality that non-medical use may cause. ${ }^{3}$ Strong associations between the extent of opioid supply and harms have been demonstrated in jurisdictions with high opioid use. ${ }^{4,5}$ Further, substantial concerns have been raised about the lack of evidence for the effectiveness of long-term use of opioids for the management of chronic non-cancer pain. ${ }^{6}$ Pharmaceutical opioids have become a public health burden through dependence, ${ }^{2}$ overdose, ${ }^{7-}$ 11 and serious morbidity from the use of high doses of combination products containing paracetamol or ibuprofen. ${ }^{12-14}$ Some attempts have been made to summarise the divergent literature on the rates of these outcomes that do occur ${ }^{15}$, although the variation in definitions and operationalisation of terms, and in the study populations, makes it difficult to be too confident about the pooled estimates ${ }^{16-18}$. There has also been concern that levels of opioid harms may be higher in rural and regional areas, where there may be significant problems related to problematic pharmaceutical opioid use. ${ }^{19-21}$

To date, many reports detailing pharmaceutical opioid utilisation have relied on data from records of reimbursed or subsidised prescriptions. ${ }^{1,2,11,22-25}$ However, often only subsided or reimbursed medicines and quantities (for example, in Australia, only those subsidised under the Pharmaceutical Benefits Scheme, or PBS) appear in these statistics, providing an incomplete picture of total pharmaceutical opioid utilisation. These data typically do not capture (1) items supplied to patients that do not meet the threshold for reimbursement (in Australia these data are only available from April 2012), or (2) unsubsidised prescriptions, including prescriptions for larger quantities or for other indications. The Australian Statistics on Medicines published by the Drug Utilisation Sub-committee of the Australian Pharmaceutical Benefits Advisory Committee (PBAC) provides PBS data and estimates of non-PBS supply from surveys of sentinel 
pharmacies, but only at a national level, which has limited utility for examining geographic supply in sub-national areas. Additionally, prescription data do not include opioids purchased without a prescription (over-the-counter (OTC) opioids); in Australia this includes many products containing codeine.

Notable increases in reported opioid prescriptions have been observed in Australia, ${ }^{1}$ particularly of oxycodone. ${ }^{2,24}$ Between 1992 and 2013, the total number of opioid prescriptions subsidised by the PBS increased fifteen-fold. ${ }^{26}$ However, these data did not capture medications that did not meet the co-payment threshold, or over-the-counter opioids. To our knowledge there has been no detailed examination of opioid sales data to quantify opioid utilisation at a national level. The aim of this study is to provide the first comprehensive overview of opioid utilisation across Australia, and to consider factors that may affect utilisation levels. Specifically, we aimed to:

1. Estimate total prescription and over-the-counter pharmaceutical opioid utilisation and determine geographic distribution across Australia;

2. Identify the proportion of utilisation accounted for by different types of opioids; and

3. Identify socio-demographic correlates of opioid utilisation.

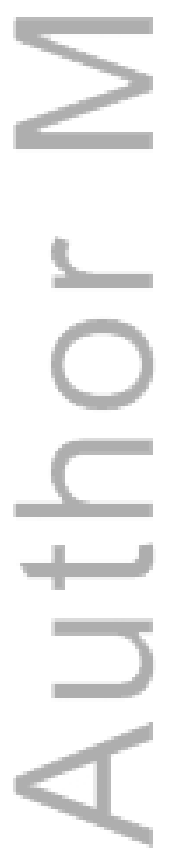

This article is protected by copyright. All rights reserved. 


\section{Methods}

\section{Opioid sales data}

A third party access request to obtain pharmaceutical opioid sales data in Australia was approved by IMS Health. These data include all pharmaceutical opioid purchases made through pharmaceutical wholesalers and manufacturers who sold direct to pharmacies in the 2013 calendar year, representing over $94 \%$ coverage of the Australian market ${ }^{27}$. This study focused on opioids sold in the community and excluded opioids supplied in hospitals. Because of the legal requirements for secure storage in pharmacies, and monitoring and recording of some opioids, the number of packs sold in pharmacies over a 12 month period very closely approximates the number used.

All opioids available in Australia that are indicated of pain were included and coded according to the World Health Organization's (WHO) Anatomical Therapeutic Classification system (http://www.whocc.no/atc ddd index/): buprenorphine (N02AE01), codeine (N02BA51, N02BE51, N02AA59, R05DA04), dextropropoxyphene (N02AC04, N02AC54), fentanyl (N02AB03), hydromorphone (N02AA03), methadone (N02AC52), morphine (N02AA01), oxycodone (N02AA05, N02AA55), and tapentadol (N02AX06) and tramadol (N02AX02). Injectable formulations were excluded as they are typically used in hospital settings; these represent an extremely small proportion of total opioids sold in the community. Formulations of methadone and buprenorphine used solely for the treatment of opioid dependence were not included. Opioids were grouped into strong prescription opioids (buprenorphine, fentanyl, hydromorphone, methadone, morphine and oxycodone as per WHO guidelines ${ }^{28}$ ), other prescription opioids (prescribed codeine, dextropropoxyphene, tapentadol and tramadol) and over-the-counter opioids (codeine products available at pharmacies without a prescription; see Appendix for more details).

Data on PBS opioid prescriptions subsidised in 2013 were also obtained to examine the magnitude of opioid sales relative to the number of prescriptions subsidised by the PBS. Australia has a publically funded universal healthcare system entitling all Australian citizens and permanent residents to a range of subsidised health services. This includes free treatment in 
public hospitals (funded jointly by Commonwealth and State/Territory governments), subsidised outpatient services including consultations with medical and selected health care professionals (funded by the Commonwealth's Medicare Benefits Scheme) and medicines prescribed in the community and private hospitals (funded by the PBS). Medicines prescribed to public hospital inpatients are covered primarily by hospital budgets. Aggregated data on all subsidised prescriptions supplied on the PBS are publically available through item supply reports (http://www.pbs.gov.au/info/statistics/dos-and-dop/dos-and-dop/). We searched these reports for each of the opioids and items included in the IMS data described above to obtain national data on the number of opioid prescriptions subsidised by the PBS in 2013 . We were unable to account for multiple packs supplied for a single prescription as data on the quantity of opioids dispensed are not publically available.

\section{Geographic coding}

IMS Health data were provided in sales "bricks" $(n=1,023)$, which are geographic boundaries containing clusters of pharmacies, developed for medicine sales and distribution purposes across Australia. Sales bricks were mapped to postcodes $(n=2,862)$, which were then mapped to 2011 Statistical Local Areas (SLAs) ( $n=1,375)$ using the Australian Bureau of Statistics' (ABS) Australian Standard Geographical Classification system. ${ }^{29}$ SLAs are a method of statistical geographic classification, providing a spatial pack comprising of areas covered by local government councils as well as unincorporated areas. Additionally, SLAs were coded according to remoteness, which was based upon the ABS' Remoteness Areas classification. ${ }^{30,}{ }^{31}$ These were "Major Cities", "Inner Regional”, "Outer Regional”, "Remote" and "Very Remote". Where SLAs covered multiple RAs, we selected the RA which covered the majority percentage of the SLA. Details of the classification of SLAs according to these groupings can be found elsewhere. ${ }^{30,}$ 31

\section{Data on characteristics of Statistical Local Areas}

Data on the characteristics of SLAs were obtained from a range of sources. The number of people in each SLA (measured in 10,000s) was obtained from ABS 2012 Population Estimates. ${ }^{32}$ Socio-demographic characteristics of residents in each SLA were obtained from the ABS Census 
(http://www.abs.gov.au/websitedbs/censushome.nsf/home/tablebuilder?opendocument\&nav pos $=240$ ). This included: proportion who were male; proportion over 65 years of age; proportion working in jobs involving physical labour (which we defined as agriculture, mining, manufacturing and construction industries); and proportion of low-income households (defined as less than AUD\$400 per week). The rate of community pharmacies in each SLA (measured as number of pharmacies per 1,000 persons) was estimated using a marketing database containing details of all pharmacies across Australia. ${ }^{33}$

\section{Analyses}

Analyses were conducted using SAS Enterprise Guide 6.1 (SAS Institute Inc., Cary, NC, USA), STATA 13 (StataCorp LP, Texas, USA), and Microsoft Excel 2010 (Microsoft, Seattle, WA). Opioid utilisation was estimated in three ways by totalling: (1) the number of packs sold, (2) the weight of active opioid ingredient in milligrams ( $\mathrm{mg}$ ) and (3) the total opioid contained in oral morphine equivalent milligrams (OME $\mathrm{mg})^{34}$.

All opioid amounts were converted into OME $\mathrm{mg}$, based on existing guidelines developed to compare across opioid preparations. ${ }^{34}$ OME are considered a better representation of opioid utilisation as opioid doses tend to vary widely between individuals, particularly among those using opioids on a long-term basis. ${ }^{35}$ In order to better represent actual utilisation of patch formulations of fentanyl and buprenorphine, the amount in mg represents the total amount released if used in accordance with the manufacturer's directions (ie. every 3 days for fentanyl $l^{36}$ and every 7 days for buprenorphine ${ }^{36}$ ), rather than the total $\mathrm{mg}$ contained in the patch. Depending on specific brands, the estimated amount of active ingredient released is approximately $43 \%$ for fentanyl patches and $17 \%$ for buprenorphine patches.

Once sales data were coded according to SLAs and RAs, total utilisation was calculated and rates estimated, based on population data from the $\mathrm{ABS}^{32}$ Confidence intervals $(95 \% \mathrm{Cls})$ were calculated for the number of packs, $\mathrm{mg}$ and OME mg per person, by jurisdiction and remoteness. A map showing the geographic distribution of pharmaceutical opioid utilisation (OME mg per person) across Australia in 2013 was generated using the ArcMap component of 
ESRI ArcGIS software. ${ }^{37}$ Bivariate and multivariate linear regressions were undertaken to examine socio-demographic correlates of the rate of pharmaceutical opioid utilisation (OME mg per person). Variables included in regression analyses were the number of pharmacies per 1,000 persons in SLAs and the ABS variables representing the characteristics of SLAs listed above. Unstandardised regression coefficients are reported in models examining the association between remoteness and total retail opioid utilisation. Unstandardised coefficients show the change in the outcome (OME mg per person) as a result of increasing remoteness. Standardised regression coefficients are reported in models examining other correlates of total retail opioid utilisation. Standardised regression coefficients indicate the effect of a one standard deviation change in the predictor variable on the outcome. They are not sensitive to the units in which the predictor is measured, and are therefore comparable.

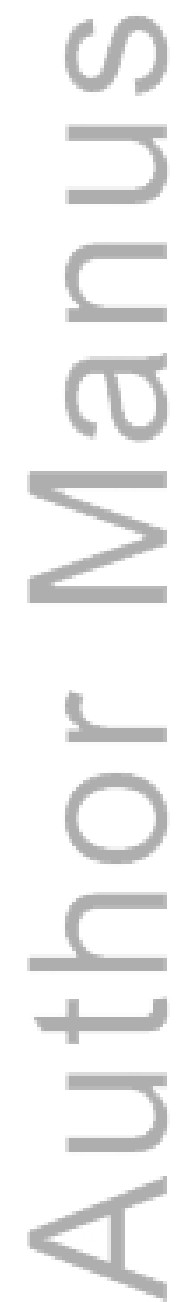

This article is protected by copyright. All rights reserved. 


\section{Results}

\section{Pack sales of opioids}

A total of 42.3 million opioid packs were sold across Australia in 2013 (Table 1). One quarter (23.8\%) of these were packs of strong prescription opioids, $39.6 \%$ other prescription opioids and $36.6 \%$ over-the-counter opioids. Codeine (both prescription and OTC) accounted for two thirds of all pack sales across Australia (29\% prescription codeine and 37\% OTC codeine). One in seven packs sold (13.7\%) were oxycodone and 9.5\%, tramadol. Dextropropoxyphene, morphine and methadone packs accounted for $1.8 \%, 1.1 \%$ and $1.3 \%$ of pack sales, respectively. Very few opioid packs sold were of tapentadol $(0.01 \%)$ and hydromorphone (0.5\%).

The number of packs sold was far higher than the number of PBS dispensings for prescription opioids (Table 1). The ratio of total packs of prescription opioids sold: PBS dispensings was 2.1:1.0, with higher ratios for methadone (5.7:1.0) and prescription codeine (3.2:1.0).

\section{Table 1 about here}

The rate of packs sold was highest in Tasmania (2.71 packs/person), followed by South Australia (2.41 packs/person), Western Australia (1.96 packs/person) and Queensland (1.91 packs/person) and New South Wales (NSW) (1.86 packs/person). Rates of packs sold for total prescription and OTC opioids (packs per person) were higher in more remote areas in NSW, Tasmania and Victoria. Rates of packs sold in Very Remote areas of NSW were six times higher than in Major Cities of NSW for the year (Table 2).

Table 2 about here

\section{Estimated utilisation in oral morphine equivalent milligrams (OME mg)}

An estimated $10,747.24 \mathrm{~kg}$ of opioids (i.e. 10.7 tonnes), measured as oral morphine equivalent $\mathrm{kg}$ (OME kg), was sold across Australia in 2013. This equated to 481.16 OME mg per person over the year. Utilisation by jurisdiction and according to remoteness is

This article is protected by copyright. All rights reserved. 
presented in Table 3. Nearly $70 \%$ of the total opioid utilisation, as measured via OME, was through strong prescription opioids, with other prescription opioids accounting for $25 \%$ and over-the-counter opioids accounting for $6 \%$ of OME utilisation. The types of opioids comprising the greatest proportion of OME utilisation were oxycodone (31\%) and tramadol (17\%). Dextropropoxyphene (<1\%) and tapentadol (<1\%) formed the smallest proportion of total OME utilisation. Although representing only $3 \%$ of pack sales nationally, fentanyl accounted for $15 \%$ of OME utilisation. Morphine accounted for $4 \%$ of OME utilisation.

Jurisdictions in crude OME utilisation are shown in Table 3. When the number of people in SLAs was accounted for, the highest rates of OME utilisation per person were in Tasmania (640.63 OME mg/person), South Australia (605.32 OME mg/person) and Queensland (521.99 OME mg/person). The lowest rate of OME utilisation per person was in the Northern Territory (272.49 OME mg/person).

There was also considerable variation in levels of OME utilisation according to remoteness (Table 3). In New South Wales, Tasmania and Victoria, the rate of total opioid utilisation per person increased with increasing remoteness, but not in other jurisdictions, although in general, major cities had lower levels of opioid utilisation than the other, more remote areas. Higher rates of OME utilisation occurred in more remote regions in New South Wales. Total OME utilisation per person in Very Remote areas (3206.55 OME mg/person) of New South Wales was eight times that of Major Cities (382.81 OME mg/person). For strong prescription opioid utilisation, OME utilisation per person in Very Remote areas (2377.00 OME $\mathrm{mg} /$ person) of New South Wales was nearly nine times higher than Major Cities (267.39 OME mg/person).

Table 4 demonstrates these associations statistically. As can be seen, more remote areas had higher rates of opioid utilisation than major cities. The associations between remoteness and opioid utilisation were much stronger for prescription opioids than for OTC opioids, with only small differences between remote and very remote areas compared to major cities in this type of opioid utilisation. 
Table 3 and 4 about here

\section{Predictors of opioid utilisation (measured as OME mg per person)}

In adjusted regression analyses (Table 5), predictors of higher opioid utilisation (measured in OME mg) per person in SLAs, across all types of opioids, were consistent. The rates of utilisation were higher in SLAs with a 1) greater proportion of males, 2) a greater proportion of people over 65 years, 3) a greater proportion of people with occupations involving physical labour, 4) more low income households, and 5) those with fewer people in SLAs (population measured in 10,000s).

\section{Insert Table 5 about here}

This article is protected by copyright. All rights reserved. 


\section{Discussion}

These are the first data estimating the full extent of pharmaceutical opioid utilisation in Australia, including supply of unsubsidised opioid items and OTC codeine. There are a number of clear findings. First, there is considerable utilisation of opioids in Australia, far higher than estimates based upon the number of subsidised prescriptions dispensed in Australia.

Second, in terms of packs sold (around 15 million packs in 2013 alone), OTC codeine is the most commonly sold opioid and is also the most accessible opioid in the community setting. Numerous studies and clinical experts have highlighted concerns about the effectiveness and adverse events of prescribed and OTC codeine ${ }^{12,38-40}$. Our findings highlight that in Australia, codeine still appears to be used as a first-line analgesic in quite high volumes despite these concerns. It is also possible that some people may be using codeine for nonmedical purposes, increasing risks of dependence ${ }^{21}$ and for adverse effects due to the other ingredients contained in these products, including paracetamol and ibuprofen. Many of these preparations contain sub-therapeutic doses that are likely to offer little clinical benefit $^{38,41}$, and have been demonstrated to have potential for serious adverse effects from escalating use and dependence. ${ }^{12-14}$ In addition to concerns about limited effectiveness, concerns have also been raised about inter-individual variations in codeine metabolism and the potential for either no/limited analgesia among poor metabolisers, or toxicity among ultra-rapid metabolisers. ${ }^{42}$ The high rates of codeine utilisation observed in this study highlight the need for further work to better understand codeine use in Australia, including determining if use represents evidence-based and effective treatment.

Third, there is also substantial utilisation per person of stronger prescription opioids, with an average of 0.5 packs of stronger prescription opioids used per person in Australia. When considering utilisation of opioids across a common metric (OMEs), it was also clear that most opioid utilisation (accounting for different potencies and strengths) is of stronger opioids. Chronic pain is highly prevalent, ${ }^{43}$ and its prevalence will continue to increase as the 
population ages. However, there is limited evidence supporting the use of opioids for the long-term management of pain. ${ }^{6}$ With the increased utilisation of strong opioids in the treatment of chronic pain, it will be important to monitor these data to detect patterns and changes in opioid use over time.

Fourth, there was clear variation in utilisation geographically, with areas outside of major cities having higher rates of utilisation of all types of opioids. Additionally, areas with indicators suggestive of greater disadvantage (e.g. more physical labour, unemployment) had higher rates of utilisation. There is evidence that regional and more remote communities may also have higher rates of problematic pharmaceutical opioid use ${ }^{19}$, with higher rates of treatment episodes per million people observed in regional and remote areas for morphine and oxycodone, ${ }^{44}$ and higher oxycodone mortality rates in rural areas in Victoria $^{8}$. Research from the United States similarly indicates morbidity and mortality related to opioids is greater in remote areas, even after adjusting for population density ${ }^{7,45}$, 46.

This may be in part related to a lack of alternative treatment options for pain in more remote areas, but may also reflect the complex social determinants of health and chronic pain, including ecological, sociological and political factors impacting opioid prescribing and healthcare provision in rural communities. ${ }^{45}$ We have previously found that among chronic non-cancer pain patients prescribed opioids, correlates of higher opioid utilisation and of problematic opioid use and dependence, included lower socio-economic status and psychiatric comorbidity ${ }^{47}$, consistent with other work with this patient group ${ }^{48-51}$. The term "adverse selection" ${ }^{51}$ has been coined to describe this apparent contradiction whereby those using higher levels of opioids are also those with greater social disadvantage as well as more complex physical and mental health problems.

It is clear that if there are intervention programs targeting the extent of inappropriate opioid prescribing and use, they need to have a particular focus on areas outside of major cities. The impact of any reduction in opioid use among some patient populations would 
need to consider potential increases in demand for non-opioid interventions in rural and regional areas, which are often difficult to access. Recent data from Canada and the United States suggest that it may also be important to target high dose prescribing, given the strong associations observed between opioid overdose risk and the use of high doses (200mg OME per day) of opioids ${ }^{52,53}$.

There were also jurisdictional differences in the rates of utilisation observed. Tasmania had the highest rates of utilisation of prescription opioids (both strong and other prescription opioids, with particularly elevated rates of other prescription opioids), and lower rates of OTC opioids compared to other jurisdictions. Given its geographic isolation from the rest of Australia, and the consistently limited availability of illicit opioids such as heroin in that State, Tasmania has traditionally had higher levels of use and injection of diverted opioids among people who use and inject illicit drugs. ${ }^{54}$ It has traditionally also been the jurisdiction with among the highest levels of opioid prescribing in the country. ${ }^{55}$ Partly in response to this, Tasmania began implementing real-time opioid prescription monitoring in recent years; it remains the only jurisdiction to date to have done so. ${ }^{55}$ Although the data we have presented here cannot be used to infer the impact of any such program and there has been varied uptake across Tasmanian pharmacies and prescribers of this program, some have suggested that real-time monitoring of opioid prescribing has led to prescribing of less restricted opioids over more restricted opioids (sometimes referred to as a "chilling effect" $\left.{ }^{\prime 56}\right)$. Direct examinations of this possibility in the United States have not suggested that there is clear support for this. ${ }^{57,58}$

It is important to note that even in Tasmania, and certainly throughout other Australian States, people who inject drugs are estimated to use only a small proportion of the total amount of pharmaceutical opioids used in the community ${ }^{59}$. It is also important to remember that people who use pharmaceutical opioids outside the bounds of a doctor's prescription do not only do so with their own medication. We have also recently demonstrated that considerable proportions of people using pharmaceutical opioids via 
tampering obtain them from someone dealing in diverted opioids, or from someone else to whom they had been prescribed. ${ }^{60,61}$

\section{Limitations}

Some limitations of this work need to be acknowledged. These data refer to packs sold, but we do not have information about the number of individuals to whom these opioids were sold, nor of the extent of utilisation per annum per individual. It is also important to be clear that the number of packs sold is not synonymous with utilisation (although the same is true for data on subsidised medicines). Furthermore, given that we assumed fentanyl and buprenorphine patches were used for the number of days recommended in prescribing guidelines, we did not account for variations in use at the individual level. The amount released from a patch provides a more reasonable reflection of use and had we taken into account the raw amounts contained in each patch, it would have resulted in much higher estimates of the actual amount of opioids used in Australia.

Higher levels of utilisation do not necessarily indicate that the use of these opioids is inappropriate or problematic in nature. The extent of diversion and/or extra-medical use of opioids is unable to be determined from these data.

Finally, this is a snapshot of opioid sales in 2013. Any subsequent changes to the regulatory environment, such as additional regulatory controls for OTC codeine products or the introduction of new abuse-deterrent opioid formulations, may result in changes in opioid utilisation in the future.

\section{Conclusions}

To our knowledge, this is one of few studies to estimate pharmaceutical opioid utilisation in detail using sales data, and to consider geographic and socio-demographic factors associated with utilisation of different opioids. There is considerable geographic variation in opioid utilisation, with areas outside of major cities having higher rates of utilisation of all types of opioids. It is likely that complex social determinants of health and pain play a role in

This article is protected by copyright. All rights reserved. 
the higher opioid utilisation in more economically-disadvantaged communities. Prescription monitoring and best practice interventions aimed at improving the treatment of chronic pain need to have a particular focus on areas outside of major cities.

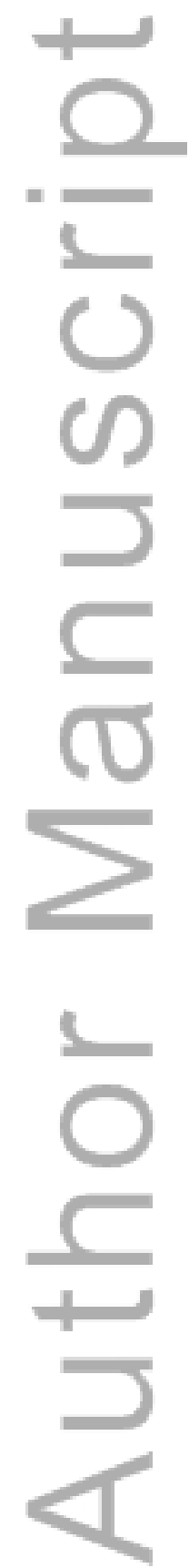

This article is protected by copyright. All rights reserved. 


\section{References}

1. Leong $M$, Murnion $B$, Haber PS. Examination of opioid prescribing in Australia from 1992 to 2007. Internal Medicine Journal. 2009; 39(10): 676-81. doi: 10.1111/j.14455994.2009.01982.x

2. Roxburgh A, Bruno R, Larance B, Burns L. Prescription of opioid analgesics and related harms in Australia. The Medical Journal of Australia. 2011; 195(5): 280-4. doi:

3. Degenhardt L, Hall W. Extent of illicit drug use and dependence, and their contribution to the global burden of disease. Lancet. 2012; 379(9810): 55-70. doi:

4. = Fischer B, Nakamura N, Urbanoski K, Rush B, Rehm J. Correlations between population levels of prescription opioid use and prescription-opioid-related substance use treatment admissions in the USA and Canada since 2001. Public Health. 2012; 126(9): 74951. doi: 10.1016/j.puhe.2012.04.010

5. Fischer B, Jones W, Rehm J. High correlations between levels of consumption and mortality related to strong prescription opioid analgesics in British Columbia and Ontario, 2005-2009. Pharmacoepidemiology and Drug Safety. 2013; 22(4): 438-42. doi: $10.1002 /$ pds.3404

6. Chou R, Turner JA, Devine EB, Hansen RN, Sullivan SD, Blazina I, et al. The Effectiveness and Risks of Long-Term Opioid Therapy for Chronic Pain: A Systematic Review for a National Institutes of Health Pathways to Prevention WorkshopEffectiveness and Risks of Long-Term Opioid Therapy for Chronic Pain. Annals of Internal Medicine. 2015; N/A(N/A): N/A-N/A. doi: 10.7326/m14-2559

7. Paulozzi LJ, Budnitz DS, Xi Y. Increasing deaths from opioid analgesics in the United States. Pharmacoepidemiology and Drug Safety. 2006; 15(9): 618-27. doi:

8. Rintoul AC, Dobbin MDH, Drummer OH, Ozanne-Smith J. Increasing deaths involving oxycodone, Victoria, Australia, 2000-09. Injury Prevention. 2011; 17(4): 254-9. doi:

9. Centers for Disease C, Prevention. Vital signs: overdoses of prescription opioid pain relievers---United States, 1999--2008. MMWR Morbidity and Mortality Weekly Report. 2011; 60(43): 1487-92. doi:

10. Office of Applied Studies-Substance Abuse and Mental Health Services Administration. Emergency department trends from DAWN: final estimates 1995 - 2002. DAWN Series D-24, DHHS publication no. (SMA) 03-3780. Rockville, MD: Department of Health and Human Services; 2003.

11. Roxburgh A, Burns L, Drummer OH, Pilgrim J, Farrell M, Degenhardt L. Trends in fentanyl prescriptions and fentanyl-related mortality in Australia. Drug and Alcohol Review. 2013; 32(3): 269-75. doi: 10.1111/dar.12033

12. Frei MY, Nielsen S, Dobbin MD, Tobin CL. Serious morbidity associated with misuse of over-the-counter codeine-ibuprofen analgesics: a series of 27 cases. The Medical Journal of Australia. 2010; 193(5): 294-6. doi:

13. Bond GR, Ho M, Woodward RW. Trends in hepatic injury associated with unintentional overdose of paracetamol (Acetaminophen) in products with and without 
opioid: an analysis using the National Poison Data System of the American Association of Poison Control Centers, 2000-7. Drug Safety. 2012; 35(2): 149-57. doi: 10.2165/11595890000000000-00000

14. Mort JR, Shiyanbola OO, Ndehi LN, Xu Y, Stacy JN. Opioid-paracetamol prescription patterns and liver dysfunction: a retrospective cohort study in a population served by a US health benefits organization. Drug Safety. 2011; 34(11): 1079-88. doi: 10.2165/11593100000000000-00000

15. Vowles KE, McEntee ML, Julnes PS, Frohe T, Ney JP, van der Goes DN. Rates of opioid misuse, abuse, and addiction in chronic pain: a systematic review and data synthesis. Pain. 2015; 156(4): 569-76. doi: 10.1097/01.j.pain.0000460357.01998.f1

16. Scholten W, Henningfield JE. A meta-analysis based on diffuse definitions and mixed quality literature is not a good fundament for decisions on treatment of chronic pain patients. Pain. 2015; 156(8): 1576-7. doi: 10.1097/j.pain.0000000000000213

17. Minozzi S, Amato L, Davoli M. Development of dependence following treatment with opioid analgesics for pain relief: a systematic review. Addiction. 2013; 108(4): 688-98. doi: 10.1111/j.1360-0443.2012.04005.x

18. Noble M, Treadwell JR, Tregear SJ, Coates VH, Wiffen PJ, Akafomo C, et al. Long-term opioid management for chronic noncancer pain. Cochrane Database of Systematic Reviews. 2010; (1): CD006605. doi:

19. 'Day C, Conroy E, Lowe J, Page J, Dolan K. Patterns of drug use and associated harms among rural injecting drug users: comparisons with metropolitan injecting drug users. Aust J Rural Health. 2006; 14(3): 120-5. doi:

20. Keyes KM, Cerda M, Brady JE, Havens JR, Galea S. Understanding the rural-urban differences in nonmedical prescription opioid use and abuse in the United States. American Journal of Public Health. 2014; 104(2): e52-9. doi: 10.2105/ajph.2013.301709

21. Nielsen S, Murnion B, Dunlop A, Degenhardt L, Demirkol A, Muhleisen P, et al. Comparing treatment-seeking codeine users and strong opioid users: Findings from a novel case series. Drug and Alcohol Review. 2015; 34(3): 304-11. doi: 10.1111/dar.12224

22. Rintoul AC, Dobbin MDH, Drummer OH, Ozanne-Smith J. Increasing deaths involving oxycodone, Victoria, Australia, 2000-09. Injury Prevention. 2010. doi: 10.1136/ip.2010.029611

23. Hollingworth SA, Gray PD, Hall WD, Najman JM. Opioid analgesic prescribing in Australia: a focus on gender and age. Pharmacoepidemiology and Drug Safety. 2015. doi: $10.1002 /$ pds.3767

24. Hollingworth SA, Symons M, Khatun M, Loveday B, Ballantyne S, Hall WD, et al. Prescribing databases can be used to monitor trends in opioid analgesic prescribing in Australia. Australian and New Zealand Journal of Public Health. 2013; 37(2): 132-8. doi: 10.1111/1753-6405.12030

25. Furu K, Wettermark B, Andersen M, Martikainen JE, Almarsdottir AB, Sørensen HT. The Nordic Countries as a Cohort for Pharmacoepidemiological Research. Basic \& Clinical Pharmacology \& Toxicology. 2010; 106(2): 86-94. doi: 10.1111/j.1742-7843.2009.00494.x 26. Blanch B, Pearson S, Haber P. An overview of the patterns of prescription opioid use, costs and related harms in Australia. Br J Clin Pharmacol. 2014; 78(5): 1159-66. doi: 
27. IMS Health. Australian Pharmaceutical Index: IMSPlus workshop manual Sydney: IMS Health Australia; 2009.

28. Zech DF, Grond S, Lynch J, Hertel D, Lehmann KA. Validation of World Health Organization Guidelines for cancer pain relief: a 10-year prospective study. Pain. 1995; 63(1): 65-76. doi:

29. Australian Bureau of Statistics. 1270055006C184 Postcode 2011 to Statistical Local Area 2011. In: Australian Bureau of Statistics, editor. Canberra: Commonwealth of Australia; 2012.

30. Australian Bureau of Statistics. 1216.0.15.003 - Australian Standard Geographical Classification (ASGC) Remoteness Area Correspondences, 2006 Canberra: Australian Bureau of Statistics; 2006.

31. = Australian Bureau of Statistics. 1216.0 - Australian Standard Geographical Classification (ASGC), July 2006. In: Australian Bureau of Statistics, editor. Canberra: Australian Bureau of Statistics,; 2006.

32. Australian Bureau of Statistics. 3235.0 Population by Age and Sex, Regions of Australia, 2012. Canberra: Australian Bureau of Statistics,; 2013.

33. Maven Marketing. List of Pharmacies and Chemists in Australia. 2014 [cited 2014 14th March]; Available from: http://www.mavenmarketing.com.au/list-of-pharmacies-inaustralia/

34. Nielsen S, Degenhardt L, Hoban B, Gisev N. Comparing opioids: A guide to estimating oral morphine equivalents (OME) in research. NDARC Technical Report No. 329. . Sydney: National Drug and Alcohol Research Centre, UNSW Australia; 2014.

35. Svendsen K, Borchgrevink P, Fredheim O, Hamunen K, Mellbye A, Dale O. Choosing the unit of measurement counts: the use of oral morphine equivalents in studies of opioid consumption is a useful addition to defined daily doses. Palliative Medicine. 2011; 25(7): 725-32. doi:

36. MIMs Australia. MIMs Online. Australia: MIMs. https://www.mimsonline.com.au/Search/Search.aspx; 2015.

37. Environmental Systems Research Institute Inc. ESRI ArcGIS Desktop 10.2. California: Esri; 2013.

38. Derry S, Karlin SM, Moore RA. Single dose oral ibuprofen plus codeine for acute postoperative pain in adults. Cochrane Database Syst Rev. 2015; 2: CD010107. doi: 10.1002/14651858.CD010107.pub3

39. Nielsen S, Tobin CL, Dobbin MD. OTC codeine: Examining the evidence for and against. Australian Pharmacist. 2012; 31(3): 236-40. doi:

40. Roxburgh A, Hall WD, Burns L, Pilgrim J, Saar E, Nielsen S, et al. Trends and characteristics of accidental and intentional codeine overdose deaths in Australia. Med J Aust. 2015; 203(7): 299. doi:

41. Toms L, Derry S, Moore RA, McQuay HJ. Single dose oral paracetamol (acetaminophen) with codeine for postoperative pain in adults. Cochrane Database Syst Rev. 2009; (1): CD001547. doi: 10.1002/14651858.CD001547.pub2 
42. Gasche $Y$, Daali $Y$, Fathi $M$, Chiappe A, Cottini S, Dayer $P$, et al. Codeine Intoxication Associated with Ultrarapid CYP2D6 Metabolism. New England Journal of Medicine. 2004; 351(27): 2827-31. doi: doi:10.1056/NEJMoa041888

43. Blyth FM, March LM, Brnabic AJM, Jorm LR, Williamson M, Cousins MJ. Chronic pain in Australia: a prevalence study. Pain. 2001; 89(2-3): 127-34. doi:

44. Nielsen S, Roxburgh A, Lintzeris N, Jefferson A, Degenhardt L. Changes in non-opioid substitution treatment episodes for pharmaceutical opioids and heroin from 2002 to 2011. Drug \& Alcohol Dependence. 2015; 149: 212-9. doi:

45. Prunuske JP, St Hill CA, Hager KD, Lemieux AM, Swanoski MT, Anderson GW, et al. Opioid prescribing patterns for non-malignant chronic pain for rural versus non-rural US adults: a population-based study using 2010 NAMCS data. BMC Health Serv Res. 2014; 14: 563. doi: 10.1186/s12913-014-0563-8

46. Havens JR, Oser CB, Leukefeld CG, Webster JM, Martin SS, O'Connell DJ, et al. Differences in prevalence of prescription opiate misuse among rural and urban probationers. Am J Drug Alcohol Abuse. 2007; 33(2): 309-17. doi: 10.1080/00952990601175078

47. Campbell G, Nielsen S, Larance B, Bruno R, Mattick R, Hall W, et al. Pharmaceutical Opioid Use and Dependence among People Living with Chronic Pain: Associations Observed within the Pain and Opioids in Treatment (POINT) Cohort. Pain Medicine. 2015; DOI: 10.1111/pme.12773. doi:

48. Clarke H, Soneji N, Ko DT, Yun L, Wijeysundera DN. Rates and risk factors for prolonged opioid use after major surgery: population based cohort study. BMJ (Clinical research ed). 2014; 348: g1251. doi: 10.1136/bmj.g1251

49. Cochran BN, Flentje A, Heck NC, Van Den Bos J, Perlman D, Torres J, et al. Factors predicting development of opioid use disorders among individuals who receive an initial opioid prescription: mathematical modeling using a database of commercially-insured individuals. Drug and Alcohol Dependence. 2014; 138: 202-8. doi: 10.1016/j.drugalcdep.2014.02.701

50. Rogers KD, Kemp A, McLachlan AJ, Blyth F. Adverse Selection? A Multi-Dimensional Profile of People Dispensed Opioid Analgesics for Persistent Non-Cancer Pain. PLoS One. 2013; 8(12): e80095. doi:

51. Sullivan MD. Who gets high-dose opioid therapy for chronic non-cancer pain? Pain. 2010; 151(3): 567-8. doi:

52. Dasgupta N, Funk MJ, Proescholdbell S, Hirsch A, RibisI KM, Marshall S. Cohort Study of the Impact of High-dose Opioid Analgesics on Overdose Mortality. Pain Medicine (Malden, Mass). 2015. doi: 10.1111/pme.12907

53. Kaplovitch E, Gomes T, Camacho X, Dhalla IA, Mamdani MM, Juurlink DN. Sex Differences in Dose Escalation and Overdose Death during Chronic Opioid Therapy: A Population-Based Cohort Study. PLoS One. 2015; 10(8): e0134550. doi: 10.1371/journal.pone.0134550

54. Stafford J, Burns L. Australia Drug Trends 2014: Findings from the Illicit Drug Reporting System (IDRS). Australian Drug Trends Series No. 127. Sydney: National Drug and Alcohol Research Centre, University of New South Wales. 2015. doi: 
55. Mattick RP, Shand F, Cohen M, Degenhardt L, Farrell M, Hall W, et al. A Review of Opioid Prescribing in Tasmania: A Blueprint for the Future. Sydney: NDARC, University of New South Wales; 2012.

56. Schmidt C. Experts worry about chilling effect of federal regulations on treating pain. Journal of the National Cancer Institute. 2005; 97(8): 554-5. doi: 10.1093/jnci/97.8.554

57. Ringwalt C, Garrettson M, Alexandridis A. The effects of North Carolina's prescription drug monitoring program on the prescribing behaviors of the state's providers. The Journal of Primary Prevention. 2015; 36(2): 131-7. doi: 10.1007/s10935-014-0381-0

58. Reisman RM, Shenoy PJ, Atherly AJ, Flowers CR. Prescription opioid usage and abuse relationships: an evaluation of state prescription drug monitoring program efficacy. Substance Abuse: Research and Treatment. 2009; 3: 41-51. doi:

59. = "Degenhardt L, Bruno R, Gilmour S, Campbell G, Mattick RP, Shand F, et al. Estimating the proportion of prescription opioid consumption in Australia that is accounted for by people who inject drugs. Drug and Alcohol Review. 2013. doi:

60. Larance B, Lintzeris N, Bruno R, Peacock A, Cama E, Ali R, et al. The characteristics of a cohort who tamper with prescribed and diverted opioid medications. Journal of Substance Abuse Treatment. 2015; doi:10.1016/j.jsat.2015.06.001. doi:

61. Peacock A, Bruno R, Cama E, Kihas I, Larance B, Lintzeris N, et al. Jurisdictional differences in opioid use, other licit and illicit drug use, and harms associated with substance use among people who tamper with pharmaceutical opioids. Drug and Alcohol Review. 2015; doi: 10.1111/dar.12279. doi:

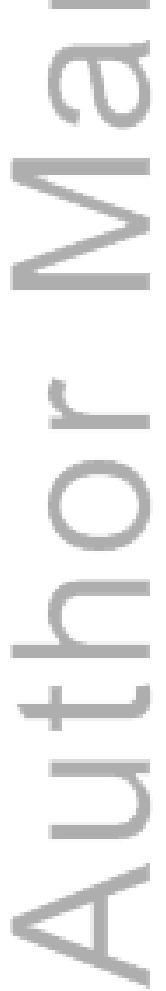

This article is protected by copyright. All rights reserved. 
Table 1: Number of packs sold and number of Australian Pharmaceutical Benefits Scheme (PBS) dispensings by opioid type, 2013

\begin{tabular}{|c|c|c|c|c|c|}
\hline \multirow{2}{*}{$=$} & \multicolumn{2}{|c|}{ Packs sold } & \multicolumn{2}{|c|}{ PBS prescriptions dispensed } & \multirow[t]{2}{*}{ Ratio of packs sold: PBS dispensings } \\
\hline & Number & $\begin{array}{c}\% \text { of total packs } \\
\text { sold }\end{array}$ & Number & $\%$ of total dispensings & \\
\hline $\begin{array}{l}\text { Strong Prescription } \\
\text { Opioids }\end{array}$ & $10,096,112$ & 23.8 & $6,238,531$ & 49.4 & 1.6 \\
\hline Buprenorphine & $1,881,695$ & 4.4 & 1381217 & 10.9 & 1.4 \\
\hline Fentanyl & 859,518 & 2 & 664509 & 5.3 & 1.3 \\
\hline Hydromorphone & 224,840 & 0.5 & 141478 & 1.1 & 1.6 \\
\hline Methadone & 541,701 & 1.3 & 94809 & 0.8 & 5.7 \\
\hline Morphine & 775,568 & 1.8 & 484459 & 3.8 & 1.6 \\
\hline Oxycodone & $5,812,790$ & 13.7 & 3472059 & 27.5 & 1.7 \\
\hline Other Prescription Opioids & $16,762,307$ & 39.6 & $6,378,686$ & 50.5 & 2.6 \\
\hline Codeine & $12,290,027$ & 29 & 3899019 & 30.9 & 3.2 \\
\hline Dextropropoxyphene & 464,247 & 1.1 & $N / A^{1}$ & -- & -- \\
\hline Tapentadol & 5,074 & 0 & $N / A^{1}$ & -- & -- \\
\hline Tramadol & $4,002,959$ & 9.5 & 2479667 & 19.6 & 1.6 \\
\hline Total prescription opioids & $26,858,419$ & 63.4 & $12,617,217$ & 99.9 & 2.1 \\
\hline Over-the-counter opioids & $15,490,207$ & 36.6 & $9,807^{2}$ & 0.1 & 1579.5 \\
\hline Codeine & $15,490,207$ & 36.6 & $9807^{2}$ & 0.1 & 1579.5 \\
\hline Total opioids & $42,348,626$ & 100 & $12,627,024$ & 100 & 3.4 \\
\hline
\end{tabular}

Note: Strong prescription opioids (morphine, oxycodone, buprenorphine, methadone, fentanyl, hydromorphone); other prescription opioids (prescription codeine,

dextropropoxyphene, tramadol, tapentadol); over-the-counter opioids (codeine products available at pharmacies without a doctor's prescription)

1. Neither tapentadol nor dextropropoxyphene were subsidised by the PBS in 2013.

2. Some OTC codeine preparations are subsidised on the PBS for eligible patients.

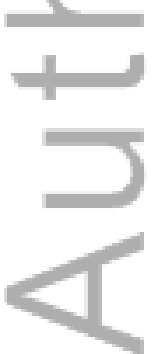

This article is protected by copyright. All rights reserved. 


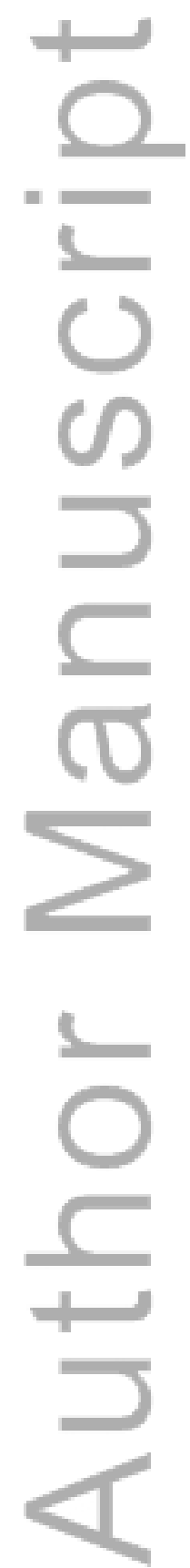

This article is protected by copyright. All rights reserved. 
Table 2: Total number of packs per person by opioid type and jurisdiction according to remoteness, $2013^{1}$

\begin{tabular}{|c|c|c|c|c|c|c|c|c|c|c|c|c|}
\hline$=$ & 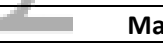 & or cities & & Regional & & r Regional & & Remote & & $y$ Remote & & Total \\
\hline $\begin{array}{l}\text { Strong } \\
\text { prescription } \\
\text { opioids }^{2}\end{array}$ & $\begin{array}{c}\text { Number of } \\
\text { packs }\end{array}$ & $\begin{array}{c}\text { Packs per } \\
\text { person [95\% } \\
\text { Cls] } \\
\end{array}$ & $\begin{array}{l}\text { Number } \\
\text { of packs }\end{array}$ & $\begin{array}{c}\text { Packs per person } \\
{[95 \% \mathrm{Cls}]}\end{array}$ & $\begin{array}{l}\text { Number } \\
\text { of packs }\end{array}$ & $\begin{array}{c}\text { Packs per person } \\
{[95 \% \mathrm{Cls}]}\end{array}$ & $\begin{array}{l}\text { Number } \\
\text { of packs }\end{array}$ & $\begin{array}{c}\text { Packs per person } \\
{[95 \% \mathrm{Cls}]}\end{array}$ & $\begin{array}{l}\text { Number } \\
\text { of packs }\end{array}$ & $\begin{array}{c}\text { Packs per } \\
\text { person }[95 \% \mathrm{Cls}]\end{array}$ & $\begin{array}{c}\text { Number of } \\
\text { packs }\end{array}$ & $\begin{array}{c}\text { Packs per } \\
\text { person [95\% } \\
\text { CIs] }\end{array}$ \\
\hline $\begin{array}{l}\text { Australian Capital } \\
\text { Territory }\end{array}$ & 165,203 & $0.45[0.45,0.45]$ & 252 & $0.41[0.36,0.47]$ & - & - & - & - & - & - & 165,455 & $0.45[0.45,0.45]$ \\
\hline New South Wales & $2,033,728$ & $0.38[0.38,0.38]$ & $1,002,123$ & $0.71[0.71,0.72]$ & 362,218 & $0.82[0.81,0.82]$ & 28,903 & $0.95[0.94,0.96]$ & 27,492 & $3.25[3.21,3.29]$ & $3,454,467$ & $0.48[0.48,0.48]$ \\
\hline Northern Territory & - & - & -1 & & 35,778 & $0.28[0.27,0.28]$ & 5,594 & $0.11[0.11,0.12]$ & 11,255 & $0.21[0.21,0.21]$ & 52,627 & $0.23[0.23,0.23]$ \\
\hline Queensland & $1,155,011$ & $0.42[0.42,0.42]$ & 497,467 & $0.55[0.54,0.55]$ & 333,982 & $0.51[0.50,0.51]$ & 32,529 & $0.42[0.41,0.42]$ & 22,080 & $0.38[0.38,0.39]$ & $2,041,068$ & $0.46[0.46,0.46]$ \\
\hline South Australia & 633,779 & $0.53[0.53,0.53]$ & 107,589 & $0.61[0.60,0.61]$ & 143,263 & $0.71[0.71,0.71]$ & 37,616 & $0.83[0.82,0.84]$ & 3,834 & $0.26[0.25,0.27]$ & 926,081 & $0.56[0.56,0.57]$ \\
\hline Tasmania & - & - & 185,542 & $0.55[0.55,0.56]$ & 119,446 & $0.72[0.72,0.73]$ & 8,429 & $1.00[0.98,1.02]$ & 3,365 & $1.38[1.33,1.42]$ & 316,782 & $0.62[0.62,0.62]$ \\
\hline Victoria & $1,464,022$ & $0.35[0.35,0.35]$ & 718,055 & $0.67[0.67,0.67]$ & 212,802 & $0.87[0.86,0.87]$ & 5,377 & $1.12[1.09,1.15]$ & - & (1) & $2,400,257$ & $0.43[0.43,0.43]$ \\
\hline Western Australia & 547,395 & $0.30[0.30,0.31]$ & 85,255 & $0.40[0.40,0.41]$ & 59,293 & $0.33[0.32,0.33]$ & 24,885 & $0.25[0.25,0.25]$ & 22,546 & $0.36[0.35,0.36]$ & 739,375 & $0.31[0.31,0.31]$ \\
\hline Australia & $5,999,138$ & $0.38[0.38,0.38]$ & $2,596,283$ & $0.63[0.63,0.63]$ & $1,266,783$ & $0.63[0.62,0.63]$ & 143,334 & $0.46[0.45,0.46]$ & 90,571 & $0.45[0.45,0.46]$ & $10,096,112$ & $0.45[0.45,0.45]$ \\
\hline $\begin{array}{l}\text { Other } \\
\text { prescription } \\
\text { opioids }^{3}\end{array}$ & $\begin{array}{c}\text { Number of } \\
\text { packs }\end{array}$ & $\begin{array}{l}\text { Packs per } \\
\text { person [95\% } \\
\text { Cls] }\end{array}$ & $\begin{array}{l}\text { Number } \\
\text { of packs }\end{array}$ & $\begin{array}{c}\text { Packs per person } \\
{[95 \% \mathrm{Cls}]}\end{array}$ & $\begin{array}{l}\text { Number } \\
\text { of packs }\end{array}$ & $\begin{array}{c}\text { Packs per person } \\
{[95 \% \mathrm{Cls}]}\end{array}$ & $\begin{array}{l}\text { Number } \\
\text { of packs }\end{array}$ & $\begin{array}{c}\text { Packs per person } \\
{[95 \% \mathrm{Cls}]}\end{array}$ & $\begin{array}{l}\text { Number } \\
\text { of packs }\end{array}$ & $\begin{array}{c}\text { Packs per } \\
\text { person }[95 \% \mathrm{Cls}]\end{array}$ & $\begin{array}{l}\text { Number of } \\
\text { packs }\end{array}$ & $\begin{array}{l}\text { Packs per } \\
\text { person [95\% } \\
\text { Cls] }\end{array}$ \\
\hline $\begin{array}{l}\text { Australian Capital } \\
\text { Territory }\end{array}$ & 215,967 & $0.59[0.59,0.59]$ & 325 & $0.53[0.48,0.59]$ & - & - & - & - & - & - & 216,292 & $0.59[0.59,0.59]$ \\
\hline New South Wales & $2,930,806$ & $0.55[0.55,0.55]$ & $1,267,753$ & $0.90[0.90,0.91]$ & 484,686 & $1.09[1.09,1.10]$ & 47,351 & $1.55[1.54,1.56]$ & 38,775 & $4.59[4.54,4.63]$ & $4,769,375$ & $0.66[0.66,0.66]$ \\
\hline Northern Territory & - & - & - & - & 68,973 & $0.53[0.53,0.54]$ & 13,766 & $0.28[0.28,0.29]$ & 21,704 & $0.41[0.40,0.41]$ & 104,442 & $0.45[0.45,0.45]$ \\
\hline Queensland & $1,876,646$ & $0.68[0.68,0.68]$ & 872,717 & $0.96[0.96,0.96]$ & 598,770 & $0.91[0.90,0.91]$ & 56,635 & $0.72[0.72,0.73]$ & 44,678 & $0.78[0.77,0.78]$ & $3,449,447$ & $0.77[0.77,0.77]$ \\
\hline South Australia & $1,293,345$ & $1.08[1.08,1.08]$ & 173,327 & $0.98[0.97,0.98]$ & 282,816 & $1.40[1.40,1.41]$ & 69,339 & $1.53[1.52,1.55]$ & 12,501 & $0.85[0.83,0.86]$ & $1,831,329$ & $1.12[1.12,1.12]$ \\
\hline Tasmania & - & - & 438,494 & $1.31[1.30,1.31]$ & 255,538 & $1.54[1.54,1.55]$ & 18,209 & $2.16[2.13,2.19]$ & 7,085 & $2.90[2.83,2.96]$ & 719,326 & $1.41[1.40,1.41]$ \\
\hline Victoria & $2,429,564$ & $0.58[0.58,0.58]$ & 963,876 & $0.90[0.90,0.90]$ & 313,828 & $1.28[1.28,1.28]$ & 8,459 & $1.77[1.73,1.80]$ & - & - & $3,715,727$ & $0.67[0.67,0.67]$ \\
\hline Western Australia & $1,451,693$ & $0.81[0.81,0.81]$ & 221,234 & $1.05[1.04,1.05]$ & 138,882 & $0.76[0.76,0.77]$ & 75,386 & $0.76[0.76,0.77]$ & 69,176 & $1.10[1.09,1.11]$ & $1,956,370$ & $0.83[0.83,0.83]$ \\
\hline Australia & $10,198,021$ & $0.65[0.65,0.65]$ & $3,937,726$ & $0.96[0.96,0.96]$ & $2,143,493$ & $1.06[1.06,1.06]$ & 289,145 & $0.92[0.92,0.92]$ & 193,918 & $0.97[0.97,0.97]$ & $16,762,308$ & $0.75[0.75,0.75]$ \\
\hline $\begin{array}{l}\text { Total prescription } \\
\text { opioids }\end{array}$ & $\begin{array}{l}\text { Number of } \\
\text { packs }\end{array}$ & $\begin{array}{l}\text { Packs per } \\
\text { person [95\% } \\
\text { Cls] }\end{array}$ & $\begin{array}{l}\text { Number } \\
\text { of packs }\end{array}$ & $\begin{array}{c}\text { Packs per person } \\
{[95 \% \mathrm{Cls}]}\end{array}$ & $\begin{array}{l}\text { Number } \\
\text { of packs }\end{array}$ & $\begin{array}{l}\text { Packs per person } \\
{[95 \% \mathrm{Cls}]}\end{array}$ & $\begin{array}{l}\text { Number } \\
\text { of packs }\end{array}$ & $\begin{array}{c}\text { Packs per person } \\
{[95 \% \mathrm{Cls}]}\end{array}$ & $\begin{array}{l}\text { Number } \\
\text { of packs }\end{array}$ & $\begin{array}{c}\text { Packs per } \\
\text { person }[95 \% \mathrm{Cls}]\end{array}$ & $\begin{array}{l}\text { Number of } \\
\text { packs }\end{array}$ & $\begin{array}{l}\text { Packs per } \\
\text { person [95\% } \\
\text { Cls] }\end{array}$ \\
\hline $\begin{array}{l}\text { Australian Capital } \\
\text { Territory }\end{array}$ & 381,169 & $1.04[1.03,1.04]$ & 577 & 0.95 & - & - & - & - & - & - & 381,746 & $1.04[1.03,1.04]$ \\
\hline New South Wales & $4,964,534$ & $0.93[0.93,0.93]$ & $2,269,876$ & $1.62[1.62,1.62]$ & 846,904 & $1.91[1.91,1.91]$ & 76,254 & $2.50[2.48,2.51]$ & 66,267 & $7.84[7.78,7.90]$ & $8,223,842$ & $1.14[1.14,1.14]$ \\
\hline Northern Territory & - & - & - & - & 104,750 & $0.81[0.81,0.82]$ & 19,360 & $0.40[0.39,0.40]$ & 32,958 & $0.62[0.61,0.62]$ & 157,068 & $0.68[0.68,0.68]$ \\
\hline Queensland & $3,031,657$ & $1.09[1.09,1.10]$ & $1,370,184$ & $1.51[1.50,1.51]$ & 932,752 & $1.41[1.41,1.42]$ & 89,164 & $1.14[1.13,1.15]$ & 66,757 & $1.16[1.15,1.17]$ & $5,490,515$ & $1.23[1.23,1.23]$ \\
\hline
\end{tabular}

This article is protected by copyright. All rights reserved. 


\begin{tabular}{|c|c|c|c|c|c|c|c|c|c|c|c|c|}
\hline South Australia & $1,927,124$ & $1.61[1.60,1.61]$ & 280,916 & $1.58[1.58,1.59]$ & 426,079 & $2.11[2.11,2.12]$ & 106,956 & $2.37[2.35,2.38]$ & 16,334 & $1.10[1.09,1.12]$ & $2,757,410$ & $1.68[1.68,1.68]$ \\
\hline Tasmania & 2 & - & 624,036 & $1.86[1.86,1.87]$ & 374,984 & $2.27[2.26,2.27]$ & 26,638 & $3.16[3.12,3.20]$ & 10,450 & $4.27[4.19,4.35]$ & $1,036,108$ & $2.03[2.02,2.03]$ \\
\hline Victoria & $3,893,587$ & $0.92[0.92,0.92]$ & $1,681,931$ & $1.57[1.57,1.57]$ & 526,631 & $2.15[2.14,2.15]$ & 13,836 & $2.89[2.84,2.94]$ & - & - & $6,115,985$ & $1.10[1.10,1.11]$ \\
\hline Western Australia & $1,999,088$ & $1.11[1.11,1.11]$ & 306,489 & $1.45[1.45,1.46]$ & 198,175 & $1.09[1.08,1.09]$ & 100,271 & $1.01[1.01,1.02]$ & 91,722 & $1.46[1.45,1.46]$ & $2,695,745$ & $1.15[1.14,1.15]$ \\
\hline Australia & $16,197,160$ & $1.03[1.03,1.03]$ & $6,534,009$ & $1.59[1.59,1.59]$ & $3,410,276$ & $1.68[1.68,1.68]$ & 432,479 & $1.37[1.37,1.38]$ & 284,489 & $1.42[1.42,1.43]$ & $26,858,419$ & $1.20[1.20,1.20]$ \\
\hline
\end{tabular}

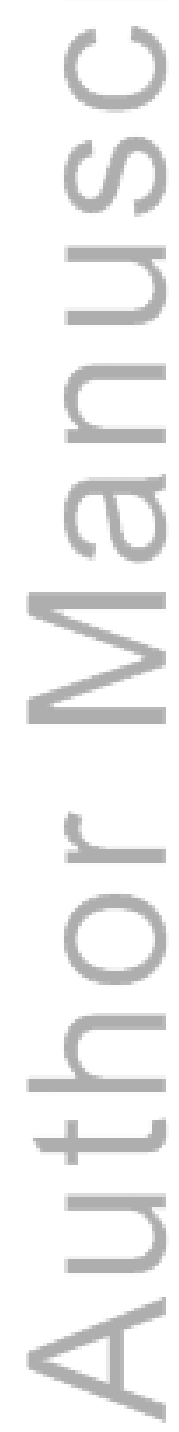

This article is protected by copyright. All rights reserved. 
Table 2 (continued): Total number of packs per person by opioid type and jurisdiction according to remoteness, 2013

\begin{tabular}{|c|c|c|c|c|c|c|c|c|c|c|c|c|}
\hline$=$ & 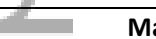 & or cities & & r Regional & & r Regional & & Remote & & fy Remote & & Total \\
\hline $\begin{array}{l}\text { Over-the-counter- } \\
\text { opioids }^{4}\end{array}$ & $\begin{array}{c}\text { Number of } \\
\text { packs }\end{array}$ & $\begin{array}{c}\text { Packs per } \\
\text { person [95\% } \\
\text { Cls] }\end{array}$ & $\begin{array}{l}\text { Number } \\
\text { of packs }\end{array}$ & $\begin{array}{c}\text { Packs per person } \\
{[95 \% \mathrm{Cls}]}\end{array}$ & $\begin{array}{l}\text { Number } \\
\text { of packs }\end{array}$ & $\begin{array}{c}\text { Packs per person } \\
{[95 \% \mathrm{Cls}]}\end{array}$ & $\begin{array}{l}\text { Number } \\
\text { of packs }\end{array}$ & $\begin{array}{c}\text { Packs per person } \\
{[95 \% \mathrm{Cls}]}\end{array}$ & $\begin{array}{l}\text { Number } \\
\text { of packs }\end{array}$ & $\begin{array}{c}\text { Packs per } \\
\text { person }[95 \% \mathrm{Cls}]\end{array}$ & $\begin{array}{c}\text { Number of } \\
\text { packs }\end{array}$ & $\begin{array}{c}\text { Packs per } \\
\text { person [95\% } \\
\text { Cls] }\end{array}$ \\
\hline $\begin{array}{l}\text { Australian Capital } \\
\text { Territory }\end{array}$ & 260,218 & $0.71[0.71,0.71]$ & 313 & $0.51[0.46,0.57]$ & - & - & - & - & - & - & 260,530 & $0.71[0.71,0.71]$ \\
\hline New South Wales & $3,727,370$ & $0.70[0.70,0.70]$ & $1,053,954$ & $0.75[0.75,0.75]$ & 337,037 & $0.76[0.76,0.76]$ & 28,421 & $0.93[0.92,0.94]$ & 20,698 & $2.45[2.42,2.48]$ & $5,167,482$ & $0.72[0.72,0.72]$ \\
\hline Northern Territory & - & - & - & - & 119,012 & $0.92[0.92,0.93]$ & 17,452 & $0.36[0.35,0.36]$ & 22,523 & $0.42[0.42,0.43]$ & 158,987 & $0.69[0.68,0.69]$ \\
\hline Queensland & $1,969,576$ & $0.71[0.71,0.71]$ & 571,677 & $0.63[0.63,0.63]$ & 437,611 & $0.66[0.66,0.67]$ & 43,455 & $0.56[0.55,0.56]$ & 31,350 & $0.54[0.54,0.55]$ & $3,053,670$ & $0.68[0.68,0.68]$ \\
\hline South Australia & 938,760 & $0.78[0.78,0.78]$ & 82,748 & $0.47[0.46,0.47]$ & 126,140 & $0.63[0.62,0.63]$ & 35,758 & $0.79[0.78,0.80]$ & 7,056 & $0.48[0.47,0.49]$ & $1,190,464$ & $0.73[0.72,0.73$ \\
\hline Tasmania & - & - & 226,889 & $0.68[0.67,0.68]$ & 111,917 & $0.68[0.67,0.68]$ & 8,985 & $1.07[1.04,1.09]$ & 2,253 & $0.92[0.88,0.96]$ & 350,045 & $0.68[0.68,0.69]$ \\
\hline Victoria & $2,618,691$ & $0.62[0.62,0.62]$ & 619,602 & $0.58[0.58,0.58]$ & 161,642 & $0.66[0.66,0.66]$ & 3,478 & $0.73[0.70,0.75]$ & - & - & $3,403,413$ & $0.61[0.61,0.62]$ \\
\hline Western Australia & $1,510,825$ & $0.84[0.84,0.84]$ & 167,813 & $0.80[0.79,0.80]$ & 102,002 & $0.56[0.56,0.56]$ & 49,837 & $0.50[0.50,0.51]$ & 75,140 & $1.19[1.18,1.20]$ & $1,905,617$ & $0.81[0.81,0.81]$ \\
\hline Australia & $11,025,441$ & $0.70[0.70,0.70]$ & $2,722,996$ & $0.66[0.66,0.66]$ & $1,395,360$ & $0.69[0.69,0.69]$ & 187,386 & $0.60[0.59,0.60]$ & 159,020 & $0.80[0.79,0.80]$ & $15,490,207$ & $0.69[0.69,0.69]$ \\
\hline $\begin{array}{l}\text { Total prescription } \\
\text { and OTC opioids }\end{array}$ & $\begin{array}{c}\text { Number of } \\
\text { packs }\end{array}$ & $\begin{array}{c}\text { Packs per } \\
\text { person [95\% } \\
\text { Cls] } \\
\end{array}$ & $\begin{array}{l}\text { Number } \\
\text { of packs }\end{array}$ & $\begin{array}{c}\text { Packs per person } \\
{[95 \% \mathrm{Cls}]}\end{array}$ & $\begin{array}{l}\text { Number } \\
\text { of packs }\end{array}$ & $\begin{array}{c}\text { Packs per person } \\
{[95 \% \mathrm{Cls}]}\end{array}$ & $\begin{array}{l}\text { Number } \\
\text { of packs }\end{array}$ & $\begin{array}{c}\text { Packs per person } \\
{[95 \% \mathrm{Cls}]}\end{array}$ & $\begin{array}{l}\text { Number } \\
\text { of packs }\end{array}$ & $\begin{array}{c}\text { Packs per } \\
\text { person }[95 \% \mathrm{Cls}]\end{array}$ & $\begin{array}{c}\text { Number of } \\
\text { packs }\end{array}$ & $\begin{array}{l}\text { Packs per } \\
\text { person [95\% } \\
\text { Cls] }\end{array}$ \\
\hline $\begin{array}{l}\text { Australian Capital } \\
\text { Territory }\end{array}$ & 641,387 & $1.75[1.74,1.75]$ & 890 & $1.46[1.36,1.56]$ & - & - & - & - & - & - & 642,277 & $1.75[1.74,1.75]$ \\
\hline New South Wales & $8,691,904$ & $1.63[1.63,1.63]$ & $3,323,830$ & $2.37[2.37,2.37]$ & $1,183,941$ & $2.67[2.67,2.68]$ & 104,675 & $3.43[3.41,3.45]$ & 86,965 & $\begin{array}{c}10.29[10.22 \\
10.36]\end{array}$ & $13,391,324$ & $1.86[1.85,1.86]$ \\
\hline Northern Territory & 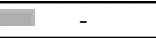 & - & - & - & 223,762 & $1.73[1.73,1.74]$ & 36,812 & $0.76[0.75,0.76]$ & 55,482 & $1.04[1.03,1.05]$ & 316,055 & $1.37[1.36,1.37]$ \\
\hline Queensland & $5,001,234$ & $1.81[1.80,1.81]$ & $1,941,860$ & $2.13[2.13,2.14]$ & $1,370,364$ & $2.08[2.07,2.08]$ & 132,619 & $1.70[1.69,1.71]$ & 98,107 & $1.70[1.69,1.71]$ & $8,544,184$ & $1.91[1.91,1.91]$ \\
\hline South Australia & $2,865,884$ & $2.39[2.38,2.39]$ & 363,665 & $2.05[2.04,2.06]$ & 552,219 & $2.74[2.73,2.74]$ & 142,714 & $3.16[3.14,3.18]$ & 23,391 & $1.58[1.56,1.60]$ & $3,947,873$ & $2.41[2.41,2.41]$ \\
\hline Tasmania & 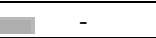 & - & 850,925 & $2.54[2.53,2.54]$ & 486,901 & $2.94[2.93,2.95]$ & 35,623 & $4.22[4.18,4.27]$ & 12,703 & $5.19[5.10,5.28]$ & $1,386,153$ & $2.71[2.71,2.71]$ \\
\hline Victoria & $6,512,277$ & $1.54[1.54,1.55]$ & $2,301,533$ & $2.15[2.14,2.15]$ & 688,273 & $2.81[2.80,2.81]$ & 17,314 & $3.62[3.56,3.67]$ & - & - & $9,519,398$ & $1.72[1.72,1.72$ \\
\hline Western Australia & $3,509,913$ & $1.95[1.95,1.95]$ & 474,302 & $2.25[2.24,2.26]$ & 300,177 & $1.65[1.64,1.66]$ & 150,107 & $1.52[1.51,1.53]$ & 166,862 & $2.65[2.63,2.66]$ & $4,601,362$ & $1.96[1.95,1.96]$ \\
\hline Australia & $27,222,600$ & $1.74[1.73,1.74]$ & $9,257,005$ & $2.25[2.25,2.25]$ & $4,805,636$ & $2.37[2.37,2.37]$ & 619,865 & $1.97[1.96,1.97]$ & 443,510 & $2.22[2.21,2.23]$ & $42,348,626$ & $1.90[1.90,1.90]$ \\
\hline
\end{tabular}

1. Note that cells without data represent areas that do not meet the particular remoteness criteria in that jurisdiction

2. Strong prescription opioids (morphine, oxycodone, buprenorphine, methadone, fentanyl, hydromorphone)

3. Other prescription opioids (prescription codeine, dextropropoxyphene, tramadol, tapentadol)

4. Over-the-counter opioids (codeine products available at pharmacies without a doctor's prescription)

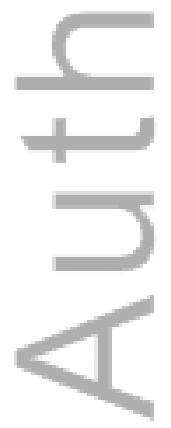

This article is protected by copyright. All rights reserved. 
Table 3: Total retail opioid utilisation (measured in oral morphine equivalent (OME) $\mathrm{mg}$ ) per person by jurisdiction according to remoteness, $2013^{1}$

\begin{tabular}{|c|c|c|c|c|c|c|c|c|c|c|c|c|}
\hline & & Major cities & & Inner Regional & & Outer Regional & & Remote & & Very Remote & & Total \\
\hline $\begin{array}{l}\text { Strong } \\
\text { prescription } \\
\text { opioids }^{2}\end{array}$ & $\begin{array}{c}\text { Total } \\
\text { OME kg }\end{array}$ & $\begin{array}{c}\text { OME mg per person } \\
{[95 \% \mathrm{Cls}]}\end{array}$ & \begin{tabular}{|c|} 
Total \\
OME kg
\end{tabular} & $\begin{array}{c}\text { OME mg per person } \\
{[95 \% \mathrm{Cls}]}\end{array}$ & $\begin{array}{c}\text { Total } \\
\text { OME kg }\end{array}$ & $\begin{array}{c}\text { OME mg per person } \\
{[95 \% \mathrm{Cls}]}\end{array}$ & \begin{tabular}{|c|} 
Total \\
OME kg
\end{tabular} & $\begin{array}{l}\text { OME mg per person } \\
{[95 \% \mathrm{Cls}]}\end{array}$ & \begin{tabular}{c|} 
Total \\
OME kg
\end{tabular} & $\begin{array}{l}\text { OME mg per person } \\
{[95 \% \mathrm{Cls}]}\end{array}$ & $\begin{array}{c}\text { Total OME } \\
\mathrm{kg}\end{array}$ & $\begin{array}{c}\text { OME mg per person } \\
{[95 \% \mathrm{Cls}]}\end{array}$ \\
\hline $\begin{array}{l}\text { Australian Capital } \\
\text { Territory }\end{array}$ & $\begin{array}{c}113.87 \\
\end{array}$ & 309.97 & 0.18 & $286.79[285.45,288.14]$ & - & - & - & - & - & & 114.05 & 309.93 \\
\hline New South Wales & $1,426.02$ & $267.39[267.37,267.40]$ & 741.03 & $528.17[528.14,528.21]$ & 281.43 & $634.77[634.70,634.84]$ & 22.98 & $752.10[751.79,752.40]$ & 20.09 & $2377.00[2375.96,2378.04]$ & $2,491.54$ & 345.16[345.15, 345.17] \\
\hline Northern Territory & & - & & - & 29.35 & $227.36[227.27,227.44]$ & 3.73 & $76.52[76.44,76.59]$ & 7.16 & $133.94[133.84,134.04]$ & 40.24 & $173.99[173.94,174.05]$ \\
\hline Queensland & 878.48 & $317.15[317.13,317.17]$ & 403.97 & $443.77[443.73,443.81]$ & 301.52 & $456.84[456.79,456.90]$ & 26.78 & $342.75[342.62,342.88]$ & 18.81 & $326.39[326.24,326.54]$ & $1,629.56$ & $364.07[364.05,364.08]$ \\
\hline South Australia & 447.62 & $372.86[372.83,372.90]$ & 76.65 & $432.20[432.10,432.30]$ & 104.55 & $518.12[518.02,518.22]$ & 29.91 & $662.09[661.85,662.33]$ & 2.74 & $185.24[185.02,185.46]$ & 661.48 & $403.44[403.41,403.47]$ \\
\hline Tasmania & - & - & 114.43 & $341.49[341.43,341.55]$ & 74.17 & $448.15[448.05,448.25]$ & 4.80 & $568.82[568.31,569.33]$ & 2.10 & $859.40[858.24,860.57]$ & 195.50 & $382.23[382.18,382.28]$ \\
\hline Victoria & $1,015.64$ & $240.95[240.94,240.97]$ & 505.44 & $471.13[471.08,471.17]$ & 152.21 & $621.03[620.93,621.13]$ & 3.82 & $798.73[797.93,799.53]$ & - & & $1,677.11$ & $302.85[302.8$ \\
\hline Western A & 417.68 & $232.21[232.18$ & 70.93 & 336.34 & 48.15 & $264.76[264.69,26$ & 20.09 & $203.18[203.0$ & 18.95 & 0.5 & 80 & $244.67[24$ \\
\hline Australia & $4,299.31$ & $274.11[274.10,2$ & $1,912.63$ & $465.35[465.33,465.37]$ & 991.38 & $489.16[489.13,489.19]$ & \begin{tabular}{|l|}
112.12 \\
\end{tabular} & $356.29[356.22,356.35]$ & 69.85 & $349.56[349.48,3$ & 5.28 & $330.64[330.6$ \\
\hline $\begin{array}{l}\text { Other } \\
\text { prescription } \\
\text { opioids }^{3}\end{array}$ & $\begin{array}{l}\text { Total } \\
\text { OME kg }\end{array}$ & $\begin{array}{l}\text { OME mg per person } \\
{[95 \% \mathrm{Cls}]}\end{array}$ & $\begin{array}{c}\text { Total } \\
\text { OME kg }\end{array}$ & $\begin{array}{c}\text { OME mg per person } \\
{[95 \% \mathrm{Cls}]}\end{array}$ & $\begin{array}{l}\text { Total } \\
\text { OME kg }\end{array}$ & $\begin{array}{c}\text { OME mg per person } \\
{[95 \% \mathrm{Cls}]}\end{array}$ & \begin{tabular}{|c|} 
Total \\
OME kg
\end{tabular} & $\begin{array}{c}\text { OME mg per person } \\
{[95 \% \mathrm{Cls}]}\end{array}$ & \begin{tabular}{c|} 
Total \\
OME kg
\end{tabular} & $\begin{array}{l}\text { OME mg per person } \\
{[95 \% \mathrm{Cls}]}\end{array}$ & $\begin{array}{c}\text { Total OME } \\
\mathrm{kg}\end{array}$ & $\begin{array}{c}\text { OME mg per person } \\
{[95 \% \mathrm{Cls}]}\end{array}$ \\
\hline $\begin{array}{l}\text { Australian Capital } \\
\text { Territory }\end{array}$ & 29.39 & 79.99 & 4 & .12[ & - & - & - & - & - & - & 13 & 79.98 \\
\hline New South Wales & 459.54 & $86.17[86.16,86.18]$ & 198.82 & $141.71[141.69,141.73]$ & 79.29 & $172.07[172.03,172.11]$ & 7.71 & $252.49[252.31,252.67]$ & 6.17 & $730.46[729.88,731.03]$ & 748.55 & $103.70[103.69,103.71]$ \\
\hline Northern Territory & - & - & 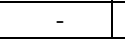 & 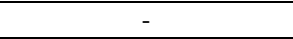 & 10.52 & $81.52[81.47,81.57]$ & 2.50 & $51.38[51.32,51.45]$ & 3.32 & $62.02[61.95,62.09]$ & 16.34 & $70.67[70.63,70.70]$ \\
\hline Queensland & 309.64 & $111.79[111.78,111.80]$ & 147.99 & $162.57[162.55,162.60]$ & 99.98 & $151.48[151.45,151.51]$ & 10.46 & $133.93[133.85,134.01]$ & 7.77 & $134.86[134.76,134.95]$ & 575.85 & $128.65[128.64,128.66]$ \\
\hline South Australia & 193.12 & $160.87[160.84,160.89]$ & 27.15 & $153.12[153.06,153.18]$ & 46.92 & $232.52[232.45,232.58]$ & 11.03 & $244.08[243.94,244.23]$ & 2.02 & $136.88[136.69,137.06]$ & 280.24 & $170.92[170.90,170.94]$ \\
\hline Tasmania & $\infty$ & - & 71.39 & $213.06[213.01,213.11]$ & 42.35 & $255.90[255.82,25$ & 2.87 & $340.46[340.06,340.85]$ & 1.15 & $471.02[470.16,4$ & 117.77 & $230.26[23$ \\
\hline Victoria & 380.68 & $90.31[90.30,9$ & 152.27 & $141.93[141.91,14$ & 52.55 & $214.40[214.34,21$ & 1.48 & $308.69[308.20,3 \mathrm{C}$ & - & - & 586.97 & $105.99[105$. \\
\hline Western Au & 262.80 & $146.10[146.08,146.12]$ & 19 & 201.49 & 27.85 & $13[153.08,15$ & 14.71 & $148.70[148.63,148.78]$ & 13.20 & {$[209.27,2$} & 361.04 & $153.41[15$ \\
\hline Australia & $1,635.17$ & $104.25[104.25,104.26]$ & 640.17 & $155.76[155.74,155.77]$ & 356.46 & $175.88[175.86,175.90]$ & 50.76 & $161.32[161.28,161.37]$ & 33.63 & $168.32[168.26,168.37]$ & $2,716.20$ & $121.61[121.60,121.61]$ \\
\hline $\begin{array}{l}\text { Total prescription } \\
\text { opioids }\end{array}$ & $\begin{array}{l}\text { Total } \\
\text { OME kg }\end{array}$ & $\begin{array}{c}\text { OME mg per person } \\
{[95 \% \mathrm{Cls}]}\end{array}$ & \begin{tabular}{|c|} 
Total \\
OME kg \\
\end{tabular} & $\begin{array}{c}\text { OME mg per person } \\
{[95 \% \mathrm{Cls}]}\end{array}$ & $\begin{array}{c}\text { Total } \\
\text { OME kg }\end{array}$ & $\begin{array}{c}\text { OME mg per person } \\
{[95 \% \mathrm{Cls}]}\end{array}$ & \begin{tabular}{|c|} 
Total \\
OME kg \\
\end{tabular} & $\begin{array}{c}\text { OME mg per person } \\
{[95 \% \mathrm{Cls}]}\end{array}$ & $\begin{array}{c}\text { Total } \\
\text { OME kg }\end{array}$ & $\begin{array}{c}\text { OME mg per person } \\
{[95 \% \mathrm{Cls}]}\end{array}$ & $\begin{array}{c}\text { Total OME } \\
\text { kg } \\
\end{array}$ & $\begin{array}{c}\text { OME mg per person } \\
{[95 \% \mathrm{Cls}]}\end{array}$ \\
\hline $\begin{array}{l}\text { Australian Capital } \\
\text { Territory }\end{array}$ & 143.26 & $389.96[389.89,390.02]$ & 0.22 & $357.91[356.41,359.42]$ & - & - & - & - & - & - & 143.48 & $389.90[389.84,389.97]$ \\
\hline New South Wales & $1,885.56$ & $353.55[353.54,353.57]$ & 939.86 & $669.89[669.84,669.93]$ & 357.72 & $34[80$ & 30.69 & 1004.55 & 26.26 & $3107.46[3106.27$ & $3,240.09$ & $448.86[44$ \\
\hline Northern Territory & - & - & - & 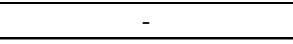 & 39.88 & $308.88[308.78,308.97]$ & 6.23 & $127.90[127.80,128.00]$ & 10.48 & $195.96[195.84,196.08]$ & 56.59 & $244.66[244.60,244.72]$ \\
\hline Queensland & $1,188.12$ & $428.94[428.91,428.96]$ & 51.97 & $606.34[606.29,606.39]$ & 401.50 & $608.33[608.27,608.39]$ & 37.24 & $476.69[476.53,476.84]$ & 26.58 & $461.25[461.07,461.42]$ & $2,205.41$ & $492.72[492.70,492.74]$ \\
\hline South Australia & 640.74 & $533.73[533.69,533.77]$ & 103.80 & $585.32[585.21,585.43]$ & 151.47 & $750.63[750.52,750.75]$ & 40.94 & $906.17[905.90,906.45]$ & 4.76 & $322.11[321.83,322.40]$ & 941.72 & $574.36[574.32,574.40]$ \\
\hline
\end{tabular}

This article is protected by copyright. All rights reserved. 


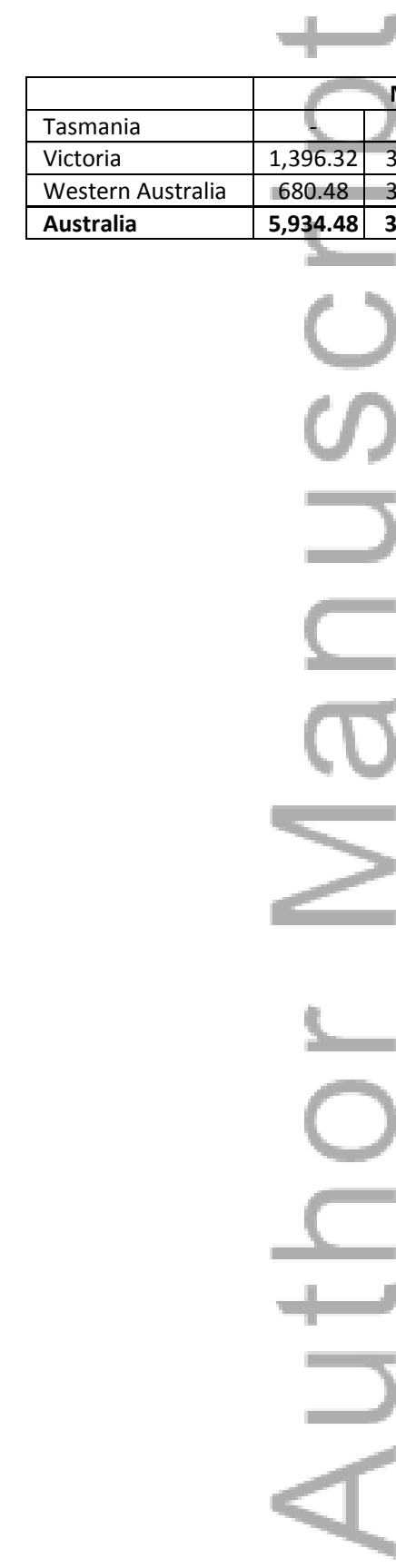

\begin{tabular}{|c|c|c|c|c|c|c|c|c|c|c|}
\hline Majo & & Inner Regional & & Outer Regional & & Remote & & Very Remote & & Total \\
\hline 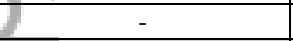 & 185.83 & $554.55[554.47,554.63]$ & 116.53 & $704.05[703.92,704.18]$ & 7.67 & $909.27[908.63,909.92]$ & 3.25 & $1330.43[1328.98,1$ & 313.28 & $612.49[612.42,612.55]$ \\
\hline $1.26[331.25,331.28]$ & 7.71 & $13.06[613.01,613.11]$ & 4.75 & 2, & 5. & 1107.42[] & - & - & 08 & 408.8 \\
\hline $8.31[378.28,378.34]$ & 113.41 & $7.83[537.73,537.93]$ & 76.00 & $417.90[417.81,417.99]$ & 34.80 & $351.89[351.77,352.00]$ & 32.14 & $10.06[509.88$, & 936.84 & $398.08[398.05,398.10]$ \\
\hline $78.36[378.35,378.37]$ & $2,552.79$ & $621.11[621.08,621.13]$ & 347.84 & $665.04[665.00,665.07]$ & 162.88 & $517.61[517.53,517.69]$ & 103.49 & $517.88[517.78,517.98]$ & $10,101.49$ & $452.25[452.24,452.26$ \\
\hline
\end{tabular}

This article is protected by copyright. All rights reserved. 
Table 3 (continued): Total retail opioid utilisation (measured in oral morphine equivalent (OME) $\mathrm{mg}$ ) per person by jurisdiction according to remoteness, $2013^{1}$

$$
=
$$

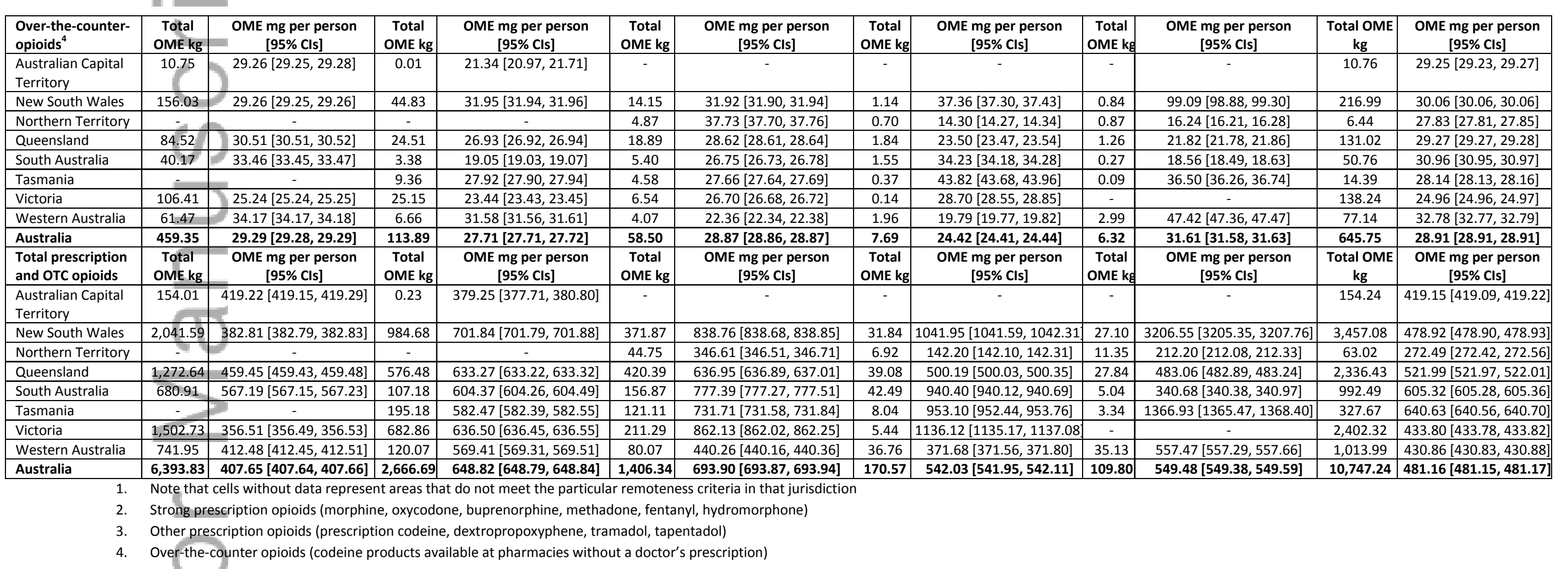

This article is protected by copyright. All rights reserved. 
Table 4: Association of remoteness area with total retail opioid utilisation (measured in oral morphine equivalent (OME) mg) per person by, 2013

\begin{tabular}{|c|c|c|c|c|c|}
\hline Unstandardised Beta (SE) & Strong prescription opioids ${ }^{1}$ & Other prescription opioids ${ }^{2}$ & $\begin{array}{c}\text { Total over-the-counter } \\
\text { opioids }^{3}\end{array}$ & Total prescription opioids & Total opioids \\
\hline Major Cities & Reference & Reference & Reference & Reference & Reference \\
\hline Inner Regional & $206.83(73.12)^{* *}$ & $64.55(27.10)^{*}$ & $-8.30(5.25)$ & $271.38(97.76)^{* *}$ & $263.08(102.11)^{*}$ \\
\hline Outer Regional & $298.74(69.71)^{* * *}$ & $130.18(25.84)^{* * *}$ & $-0.80(5.01)$ & $428.93(93.20)^{* * *}$ & $428.13(97.34)^{* * *}$ \\
\hline Remote & $515.42(118.67)^{* * *}$ & $294.10(43.99)^{* * *}$ & $22.35(8.52)^{* *}$ & $809.52(158.66)^{* * *}$ & $831.88(165.71)^{* * *}$ \\
\hline Very Remote & $471.14(107.18)^{* * *}$ & $216.14(39.73)^{* * *}$ & $20.13(7.70)^{* *}$ & $687.28(143.31)^{* * *}$ & $707.41(149.68)^{* * *}$ \\
\hline
\end{tabular}

Results of linear regressions, with remoteness area predicting OME rate per person for each type of opioid.

$* \mathrm{p}<.05 \quad * * \mathrm{p}<.01 * * * \mathrm{p}<.001$

1. Strong prescription opioids (morphine, oxycodone, buprenorphine, methadone, fentanyl, hydromorphone)

2. Other prescription opioids (prescription codeine, dextropropoxyphene, tramadol, tapentadol)

3. Over-the-counter opioids (codeine products available at pharmacies without a doctor's prescription)

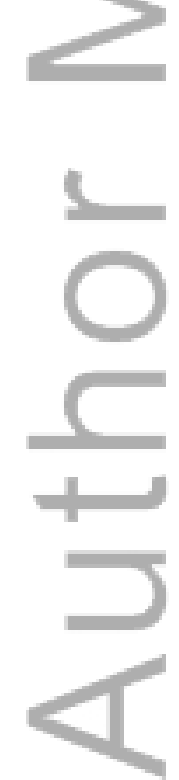

This article is protected by copyright. All rights reserved. 
Figure 1: Total opioid utilisation per person (oral morphine equivalent (OME) mg) by Statistical Local Area, 2013
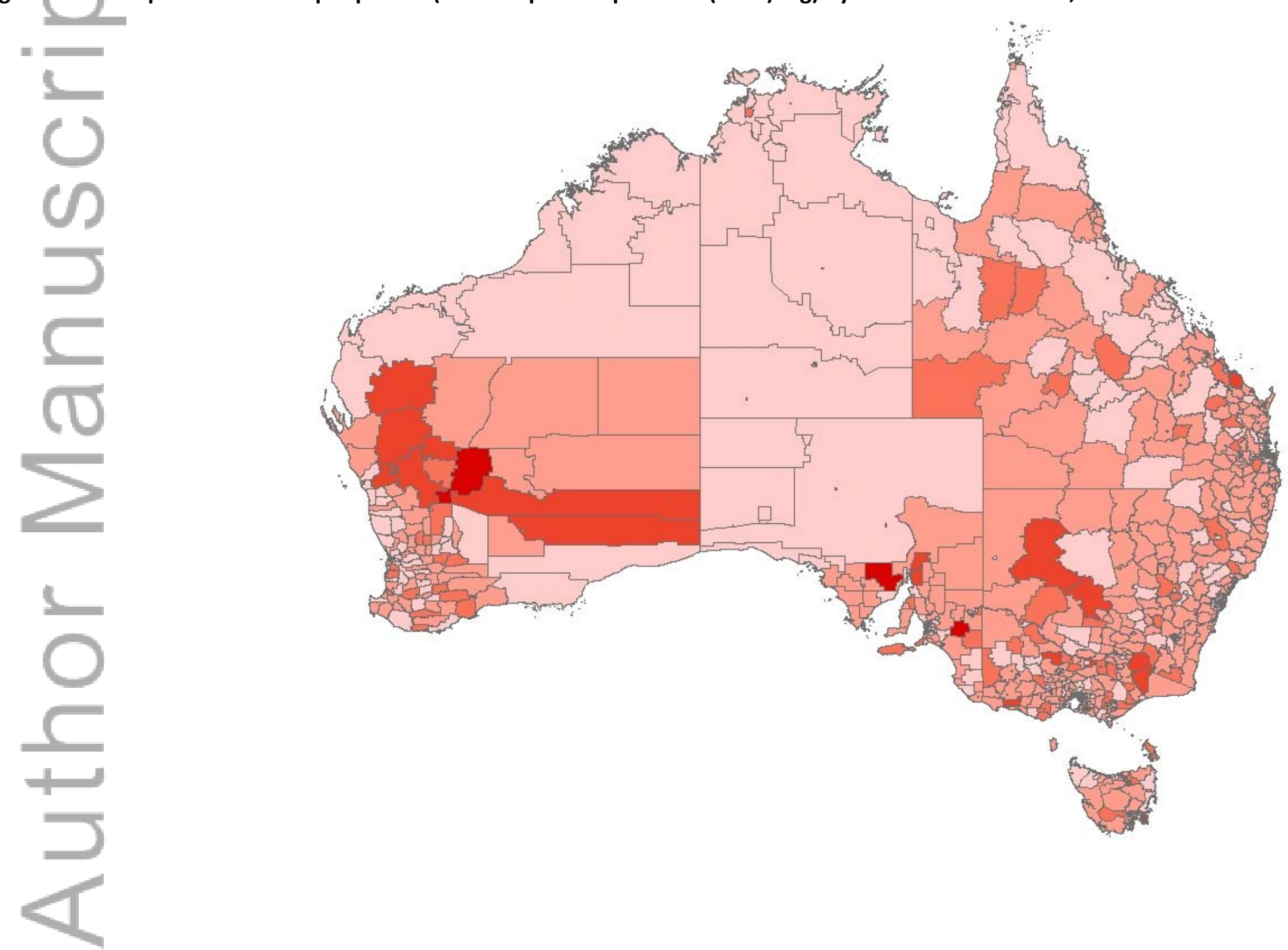

This article is protected by copyright. All rights reserved. 
Australia (2011 Statistical Local Areas)

Total opioid utilisation (OME $\mathrm{mg}$ ) per person

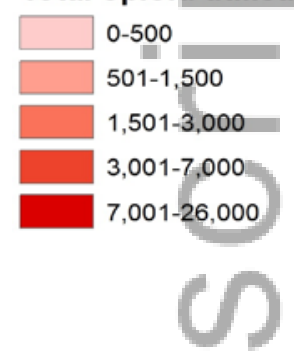

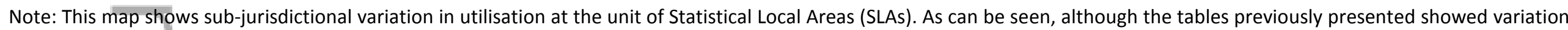
in opioid utilisation across jurisdictions, there is also considerable variation within jurisdictions in the extent of opioid utilisation.

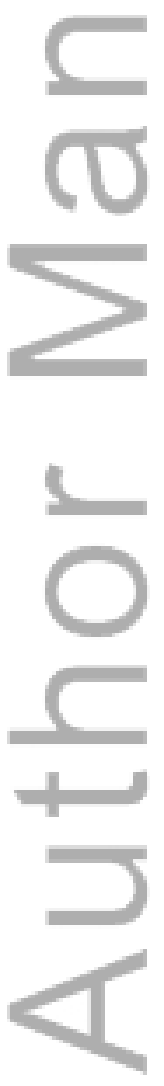


Table 5: Predictors of opioid utilisation (measured in oral morphine equivalent (OME) mg) per person by Statistical Local Area, 2013

\begin{tabular}{|c|c|c|c|c|c|c|}
\hline \multirow{2}{*}{ Standardised Beta (SE) } & \multicolumn{2}{|c|}{ Total opioids } & \multicolumn{2}{|c|}{ Total prescription opioids } & \multicolumn{2}{|c|}{ Total over the counter opioids ${ }^{3}$} \\
\hline & Unadjusted & Adjusted & Unadjusted & Adjusted & Unadjusted & Adjusted \\
\hline$\%$ male & $0.13(9.73)^{* * *}$ & $0.11(13.68)^{* * *}$ & \begin{tabular}{|l}
$0.13(9.33)^{* * *}$ \\
\end{tabular} & $0.10(13.08)^{* *}$ & $0.19(.049)^{* * *}$ & $0.22(0.71)^{* * *}$ \\
\hline$\%$ over 65 years of age & $0.13(6.71)^{* * *}$ & $0.10(7.76)^{* * *}$ & $0.13(6.42)^{* * *}$ & $0.10(7.42)^{* * *}$ & $0.00(0.34)$ & $0.05(0.40)$ \\
\hline$\%$ physical labour & $0.19(2.52)^{* * *}$ & $0.07(3.02)^{*}$ & $0.19(2.41)^{* * *}$ & $0.08(2.89)^{*}$ & $0.09(0.13)^{* * *}$ & $-0.03(0.16)$ \\
\hline$\%$ low income households & $0.20(3.51)^{* * *}$ & $0.14(3.83)^{* * *}$ & $0.20(3.36)^{* * *}$ & $0.14(3.67)^{* * *}$ & $0.06(0.18)^{*}$ & $0.05(0.20)$ \\
\hline Pharmacies per 1,000 persons & $0.02(9.14)$ & $-0.02(10.77)$ & $0.02(8.76)$ & $-0.02(10.30)$ & $0.05(0.46)$ & $-0.01(0.56)$ \\
\hline \multirow[t]{3}{*}{ \# of people (in 10,000s) } & $-0.14(16.66)^{* * *}$ & $-0.09(16.66)^{* *}$ & $-0.14(15.97)^{* * *}$ & $-0.09(15.94)^{* *}$ & $-0.11(0.85)^{* * *}$ & $-0.06(0.87)^{*}$ \\
\hline & \multicolumn{2}{|c|}{ Strong prescription opioids ${ }^{1}$} & \multicolumn{2}{|c|}{ Other prescription opioids ${ }^{2}$} & & \\
\hline & Unadjusted & Adjusted & Unadjusted & Adjusted & & \\
\hline 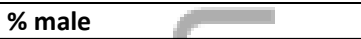 & $0.12(6.96)^{* * *}$ & $0.10(9.77)^{* *}$ & $0.14(2.60)^{* * *}$ & $0.10(3.63)^{* *}$ & & \\
\hline$\%$ over 65 years of age & $0.14(4.79)^{* * *}$ & $0.12(5.54)^{* * *}$ & $0.11(1.80)^{* * *}$ & $0.05(2.06)$ & & \\
\hline \% physical labour & $0.16(1.81)^{* * *}$ & $0.05(2.16)$ & $0.26(0.66)^{* * *}$ & $0.15(0.80)^{* * *}$ & & \\
\hline \% low income households & $0.18(2.50)^{* * *}$ & $0.12(2.74)^{* * *}$ & $0.24(0.94)^{* * *}$ & $0.18(1.02)^{* * *}$ & & \\
\hline Pharmacies per 1,000 persons & $0.02(6.53)$ & $-0.02(7.70)$ & $0.01(2.45)$ & $-0.03(2.86)$ & & \\
\hline \# of people (in 10,000s) & $-0.13(11.91)^{* * *}$ & $-0.09(11.90)^{* * *}$ & $-0.14(4.46)^{* * *}$ & $-0.07(4.42)^{* *}$ & & \\
\hline
\end{tabular}

1. Strong prescription opioids (morphine, oxycodone, buprenorphine, methadone, fentanyl, hydromorphone)

2. Other prescription opioids (prescription codeine, dextropropoxyphene, tramadol, tapentadol)

3. Over-the-counter opioids (codeine products available at pharmacies without a doctor's prescription)

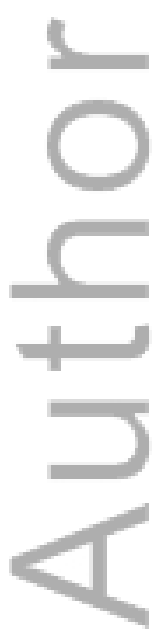

This article is protected by copyright. All rights reserved. 


\section{Appendix}

\section{Appendix A1. The regulations and availability of codeine preparations in Australia ${ }^{1}$}

\begin{tabular}{|c|c|c|c|}
\hline Schedule & Description & Rules & Codeine preparations \\
\hline \multicolumn{4}{|c|}{ Prescription codeine } \\
\hline Schedule 8 & $\begin{array}{l}\text { Controlled Drug/Drugs of } \\
\text { Addiction }\end{array}$ & $\begin{array}{l}\text { Must be prescribed by an authorised healthcare professional, who } \\
\text { may need another permit to prescribe these medicines. May be } \\
\text { supplied in hospital or purchased from a pharmacy with a } \\
\text { prescription. }\end{array}$ & $\begin{array}{l}\text { - } 30 \mathrm{mg} \text { codeine tablets } \\
\text { - } 5 \mathrm{mg} / \mathrm{mL} \text { codeine linctus }\end{array}$ \\
\hline Schedule & $\begin{array}{l}\text { Prescription Only } \\
\text { Medicine }\end{array}$ & $\begin{array}{l}\text { Must be prescribed by an authorised healthcare professional. May } \\
\text { be supplied in hospital or purchased from a pharmacy with a } \\
\text { prescription. }\end{array}$ & $\begin{array}{l}\text { - Codeine } 30 \mathrm{mg} / \text { paracetamol } 500 \mathrm{mg} \\
\text { combinations } \\
\text { - Codeine } 30 \mathrm{mg} / \text { paracetamol } \\
450 \mathrm{mg} / 5 \mathrm{mg} \text { doxylamine }\end{array}$ \\
\hline \multicolumn{4}{|c|}{ Over-the-counter analgesic preparations containing codeine } \\
\hline Schedule 3 & Pharmacist Only Medicine & $\begin{array}{l}\text { Only available behind the counter at a pharmacy, but no } \\
\text { prescription required. A pharmacist must be consulted prior to } \\
\text { purchase. }\end{array}$ & 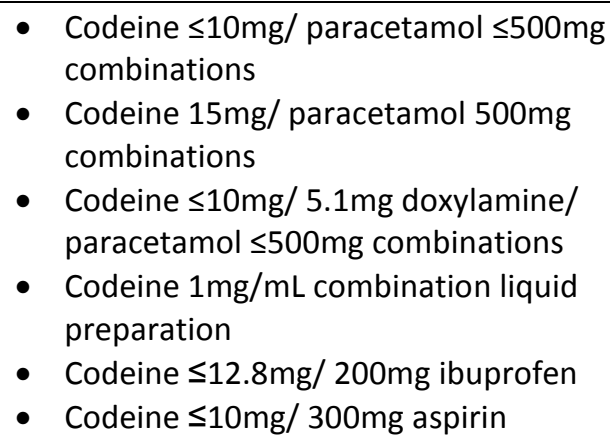 \\
\hline
\end{tabular}

${ }^{1}$ Adapted from the National Prescribing Service. Medicine schedules and availability. 2015 [cited 29 June 2015]. Available from: http://www.nps.org.au/topics/how-to-bemedicinewise/regulation-clinical-trials/medicine-schedules-availability/.

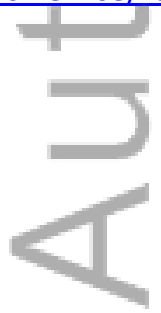


Appendix Table A1: Total retail opioid utilisation (measured in mgs and OME mgs) and packs per person per person, by jurisdiction, 2013

\begin{tabular}{|c|c|c|c|c|c|c|}
\hline Oxycodone & Number of packs & $\begin{array}{c}\text { Packs per person [95\% } \\
\text { Cls] }\end{array}$ & Crude utilisation kgs & $\begin{array}{c}\text { mg per person } \\
{[95 \% \mathrm{Cls}]}\end{array}$ & Total OME kg & OME mg per person [95\% Cls \\
\hline Australian Capital Territory & 108,832 & $0.30[0.29,0.30]$ & 37.30 & $101.36[101.33,101.39]$ & 55.95 & $152.04[152.00,152.08]$ \\
\hline New South Wa & $2,143,999$ & $0.30[0.30,0.30]$ & 776.60 & $107.58[107.58,107.59]$ & $1,164.90$ & $161.38[161.37,161.39]$ \\
\hline Northern Territory & 27,532 & $0.12[0.12,0.12]$ & 7.83 & $33.87[33.84,33.89]$ & 11.75 & $50.80[50.77,50.83]$ \\
\hline Queensland & $1,180,637$ & $0.26[0.26,0.26]$ & 451.98 & $100.98[100.97,100.99]$ & 677.97 & $151.47[151.46,151.48]$ \\
\hline South Austral & 429,898 & $0.26[0.26,0.26]$ & 142.02 & $86.62[86.60,86.63]$ & 213.03 & $129.93[129.91,129.94]$ \\
\hline Tasmania & 154,543 & $0.30[0.30,0.30]$ & 49.31 & $96.40[96.37,96.42]$ & 73.96 & $144.60[144.56,144.63]$ \\
\hline Victoria & $1,405,920$ & $0.25[0.25,0.25]$ & 458.09 & $82.72[82.71,82.73]$ & 687.13 & $124.08[124.07,124.09]$ \\
\hline Western Australia & 361,428 & $0.15[0.15,0.15]$ & 135.34 & $57.51[57.50,57.52]$ & 203.01 & $86.26[86.25,86.27]$ \\
\hline Australia & $5,812,790$ & $0.26[0.26,0.26]$ & $2,058.46$ & $92.16[92.15,92.16]$ & $3,087.68$ & $138.24[138.23,138.24]$ \\
\hline Codeine (prescribed) & Number of packs & $\begin{array}{l}\text { Packs per person [95\% } \\
\text { Cls] }\end{array}$ & Crude utilisation kgs & $\begin{array}{c}\text { mg per person } \\
{[95 \% \mathrm{Cls}]}\end{array}$ & Total OME kg & OME mg per person [95\% Cls \\
\hline Australian Capital Territory & 170,655 & $0.46[0.46,0.47]$ & 102.85 & $279.50[279.44,279.55]$ & 13.37 & $36.33[36.32,36.35]$ \\
\hline New South Wales & $3,515,660$ & $0.49[0.49,0.49]$ & $2,120.99$ & $293.83[293.81,293.84]$ & 275.73 & $38.20[38.19,38.20]$ \\
\hline Northern Territory & 77,960 & $0.34[0.33,0.34]$ & 47.12 & $203.73[203.67,203.79]$ & 6.13 & $26.48[26.46,26.51]$ \\
\hline Queensland & $2,525,431$ & $0.56[0.56,0.56]$ & $1,519.37$ & $339.45[339.43,339.47]$ & 197.52 & $44.13[44.12,44.13]$ \\
\hline South Australia & $1,399,636$ & $0.85[0.85,0.86]$ & 842.39 & $513.77[513.74,513.81]$ & 109.51 & $66.79[66.78,66.80]$ \\
\hline Tasmania & 543,735 & $1.06[1.06,1.07]$ & 326.90 & $639.13[639.06,639.20]$ & 42.50 & $83.09[83.06,83.11]$ \\
\hline Victoria & $2,742,683$ & $0.50[0.49,0.50]$ & $1,657.95$ & $299.39[299.37,299.40]$ & 215.53 & $38.92[38.92,38.93]$ \\
\hline Western Australia & $1,314,267$ & $0.56[0.56,0.56]$ & 791.61 & $336.37[336.35,336.39]$ & 102.91 & $43.73[43.72,43.74]$ \\
\hline Australia & $12,290,027$ & $0.55[0.55,0.55]$ & $7,409.19$ & $331.71[331.71,331.72]$ & 963.19 & $43.12[43.12,43.13]$ \\
\hline
\end{tabular}

This article is protected by copyright. All rights reserved. 


\begin{tabular}{|c|c|c|c|c|c|c|}
\hline Fentanyl & Number of packs & $\begin{array}{c}\text { Packs per person [95\% } \\
\text { Cls] }\end{array}$ & Crude utilisation kgs & $\begin{array}{c}\text { mg per person } \\
{[95 \% \mathrm{Cls}]}\end{array}$ & Total OME kg & OME mg per person [95\% Cls] \\
\hline Australian Capital Territory & 13,148 & $0.04[0.04,0.04]$ & 0.20 & $0.53[0.53,0.54]$ & 24.40 & $66.32[66.29,66.34]$ \\
\hline New South Wales & 302,277 & $0.04[0.04,0.04]$ & 4.37 & $0.60[0.60,0.61]$ & 544.67 & $75.45[75.45,75.46]$ \\
\hline Northern Territory & 2,436 & $0.01[0.01,0.01]$ & 0.03 & $0.13[0.13,0.14]$ & 3.87 & $16.75[16.73,16.76]$ \\
\hline Queensland & 198,275 & $0.04[0.04,0.04]$ & 3.00 & $0.67[0.67,0.67]$ & 374.52 & $83.67[83.66,83.68]$ \\
\hline South Austr & 96,286 & $0.06[0.06,0.06]$ & 1.23 & $0.75[0.75,0.75]$ & 153.86 & $93.84[93.83,93.86]$ \\
\hline Tasmania & 10,357 & $0.02[0.02,0.02]$ & 0.14 & $0.27[0.27,0.27]$ & 17.12 & $33.47[33.45,33.48]$ \\
\hline Victoria & 173,446 & $0.03[0.03,0.03]$ & 2.45 & $0.44[0.44,0.44]$ & 305.51 & $55.17[55.16,55.17]$ \\
\hline Western Australia & 63,293 & $0.03[0.03,0.03]$ & 0.85 & $0.36[0.36,0.36]$ & 106.25 & $45.15[45.14,45.16]$ \\
\hline Australia & 859,518 & $0.04[0.04,0.04]$ & 12.26 & $0.55[0.55,0.55]$ & $1,530.21$ & $68.51[68.50,68.51]$ \\
\hline Hydromorphone & Number of packs & $\begin{array}{l}\text { Packs per person [95\% } \\
\text { Cls] }\end{array}$ & Crude utilisation kgs & $\begin{array}{c}\text { mg per person } \\
{[95 \% \mathrm{Cls}]}\end{array}$ & Total OME kg & OME mg per person [95\% Cls] \\
\hline Australian Capital Territory & 4,260 & $0.01[0.01,0.01]$ & 1.13 & $3.08[3.07,3.08]$ & 5.67 & $15.40[15.38,15.41]$ \\
\hline New South Wales & 71,940 & $0.01[0.01,0.01]$ & 15.86 & $2.20[2.20,2.20]$ & 79.31 & $10.99[10.98,10.99]$ \\
\hline Northern Territory & 295 & $0.00[0.00,0.00]$ & 0.07 & $0.32[0.32,0.32]$ & 0.37 & $1.61[1.60,1.61]$ \\
\hline Queensland & 58,057 & $0.01[0.01,0.01]$ & 14.03 & $3.13[3.13,3.14]$ & 70.14 & $15.67[15.67,15.67]$ \\
\hline South Australia & 14,660 & $0.01[0.01,0.01]$ & 3.01 & $1.83[1.83,1.84]$ & 15.03 & $9.17[9.16,9.17]$ \\
\hline Tasmania & 1,456 & $0.00[0.00,0.00]$ & 0.30 & $0.59[0.59,0.59]$ & 1.51 & $2.94[2.94,2.95]$ \\
\hline Victoria & 44,707 & $0.01[0.01,0.01]$ & 9.26 & $1.67[1.67,1.67]$ & 46.29 & $8.36[8.36,8.36]$ \\
\hline Western Australia & 29,466 & $0.01[0.01,0.01]$ & 6.30 & $2.68[2.67,2.68]$ & 31.49 & $13.38[13.38,13.39]$ \\
\hline Australia & 224,840 & $0.01[0.01,0.01]$ & 49.96 & $2.24[2.24,2.24]$ & 249.80 & $11.18[11.18,11.19]$ \\
\hline
\end{tabular}

This article is protected by copyright. All rights reserved. 


\begin{tabular}{|c|c|c|c|c|c|c|}
\hline Methadone & Number of packs & $\begin{array}{c}\text { Packs per person [95\% } \\
\text { Cls] }\end{array}$ & Crude utilisation kgs & $\begin{array}{c}\text { mg per person } \\
{[95 \% \mathrm{Cls}]}\end{array}$ & Total OME kg & OME mg per person [95\% Cls] \\
\hline Australian Capital Territory & 4,922 & $0.01[0.01,0.01]$ & 0.99 & $2.68[2.68,2.69]$ & 4.64 & $12.60[12.59,12.61]$ \\
\hline New South Wales & 153,633 & $0.02[0.02,0.02]$ & 55.69 & $7.71[7.71,7.72]$ & 261.73 & $36.26[36.25,36.26]$ \\
\hline Northern Territory & 6,523 & $0.03[0.03,0.03]$ & 1.36 & $5.88[5.87,5.89]$ & 6.39 & $27.62[27.60,27.64]$ \\
\hline Queensland & 86,777 & $0.02[0.02,0.02]$ & 33.21 & $7.42[7.42,7.42]$ & 156.10 & $34.87[34.87,34.88]$ \\
\hline South Australia & 80,911 & $0.05[0.05,0.05]$ & 20.76 & $12.66[12.66,12.67]$ & 97.58 & $59.51[59.50,59.52]$ \\
\hline Tasmania & 23,640 & $0.05[0.05,0.05]$ & 8.68 & $16.97[16.96,16.99]$ & 40.81 & $79.78[79.76,79.81]$ \\
\hline Victoria & 123,251 & $0.02[0.02,0.02]$ & 57.85 & $10.45[10.44,10.45]$ & 271.88 & $49.09[49.09,49.10]$ \\
\hline Western Australia & 62,045 & $0.03[0.03,0.03]$ & 22.30 & $9.48[9.47,9.48]$ & 104.82 & $44.54[44.53,44.55]$ \\
\hline Australia & 541,701 & $0.02[0.02,0.02]$ & 200.83 & $8.99[8.99,8.99]$ & 943.92 & $42.26[42.26,42.26]$ \\
\hline Morphine & Number of packs & $\begin{array}{c}\text { Packs per person [95\% } \\
\text { Cls] }\end{array}$ & Crude utilisation kgs & $\begin{array}{c}\text { mg per person } \\
{[95 \% \mathrm{Cls}]}\end{array}$ & Total OME kg & OME mg per person [95\% Cls] \\
\hline Australian Capital Territory & 11,815 & $0.03[0.03,0.03]$ & 14.92 & $40.54[40.52,40.56]$ & 14.92 & $40.54[40.52,40.56]$ \\
\hline New South Wales & 212,920 & $0.03[0.03,0.03]$ & 228.94 & $31.72[31.71,31.72]$ & 228.94 & $31.72[31.71,31.72]$ \\
\hline Northern Territory & 9,594 & $0.04[0.04,0.04]$ & 15.47 & $66.90[66.87,66.93]$ & 15.47 & $66.90[66.87,66.93]$ \\
\hline Queensland & 174,378 & $0.04[0.04,0.04]$ & 222.30 & $49.66[49.66,49.67]$ & 222.30 & $49.66[49.66,49.67]$ \\
\hline South Australia & 110,034 & $0.07[0.07,0.07]$ & 110.08 & $67.14[67.12,67.15]$ & 110.08 & $67.14[67.12,67.15]$ \\
\hline Tasmania & 25,951 & $0.05[0.05,0.05]$ & 21.08 & $41.21[41.20,41.23]$ & 21.08 & $41.21[41.20,41.23]$ \\
\hline Victoria & 176,932 & $0.03[0.03,0.03]$ & 189.66 & $34.25[34.24,34.25]$ & 189.66 & $34.25[34.24,34.25]$ \\
\hline Western Australia & 53,945 & $0.02[0.02,0.02]$ & 66.57 & $28.29[28.28,2.29]$ & 66.57 & $28.29[28.28,28.29]$ \\
\hline Australia & 775,568 & $0.03[0.03,0.03]$ & 869.01 & $38.91,38.90,38.91]$ & 869.01 & $38.91[38.90,38.91]$ \\
\hline
\end{tabular}

This article is protected by copyright. All rights reserved. 


\begin{tabular}{|c|c|c|c|c|c|c|}
\hline Buprenorphine & Number of packs & $\begin{array}{c}\text { Packs per person [95\% } \\
\text { Cls] }\end{array}$ & Crude utilisation kgs & $\begin{array}{c}\text { mg per person } \\
{[95 \% \mathrm{Cls}]}\end{array}$ & Total OME kg & OME mg per person $[95 \% \mathrm{Cls}]$ \\
\hline Australian Capital Territory & 22,478 & $0.06[0.06,0.06]$ & 0.08 & $0.22[0.22,0.22]$ & 8.47 & $23.03[23.01,23.04]$ \\
\hline New South Wales & 569,697 & $0.08[0.08,0.08]$ & 2.05 & $0.28[0.28,0.28]$ & 212.00 & $29.37[29.37,29.37]$ \\
\hline Northern Territory & 6,248 & $0.03[0.03,0.03]$ & 0.02 & $0.10[0.10,0.10]$ & 2.39 & $10.32[10.31,10.33]$ \\
\hline Queensland & 342,945 & $0.08[0.08,0.08]$ & 1.24 & $0.28[0.28,0.28]$ & 128.55 & $28.72[28.71,28.72]$ \\
\hline South Austr & 194,291 & $0.12[0.12,0.12]$ & 0.69 & $0.42[0.42,0.42]$ & 71.90 & $43.85[43.84,43.86]$ \\
\hline Tasmania & 100,835 & $0.20[0.20,0.20]$ & 0.39 & $0.77[0.77,0.77]$ & 41.04 & $80.23[80.20,80.25]$ \\
\hline Victoria & 476,001 & $0.09[0.09,0.09]$ & 1.70 & $0.31[0.31,0.31]$ & 176.65 & $31.90[31.89,31.90]$ \\
\hline Western Australia & 169,199 & $0.07[0.07,0.07]$ & 0.62 & $0.26[0.26,0.27]$ & 63.66 & $27.05[27.04,27.06]$ \\
\hline Australia & $1,881,695$ & $0.08[0.08,0.08]$ & 6.80 & $0.30[0.30,0.30]$ & 704.66 & $31.55[31.55,31.55]$ \\
\hline Tapentadol & Number of packs & $\begin{array}{c}\text { Packs per person [95\% } \\
\text { Cls] }\end{array}$ & Crude utilisation kgs & $\begin{array}{c}\text { mg per person } \\
{[95 \% \mathrm{Cls}]}\end{array}$ & Total OME kg & OME mg per person $[95 \% \mathrm{Cls}]$ \\
\hline Australian Capital Territory & 84 & $0.00[0.00,0.00]$ & 0.19 & $0.51[0.51,0.51]$ & 0.08 & $0.20[0.20,02.21]$ \\
\hline New South Wales & 2,017 & $0.00[0.00,0.00]$ & 7.88 & $1.09[1.09,1.09]$ & 3.15 & $0.44[0.44,0.44]$ \\
\hline Northern Territory & 0 & - & 0 & - & 0 & - \\
\hline Queensland & 251 & $0.00[0.00,0.00]$ & 0.82 & $0.18[0.18,0.18]$ & 0.33 & $0.07[0.07,0.07]$ \\
\hline South Australia & 341 & $0.00[0.00,0.00]$ & 1.07 & $0.65[0.65,0.66]$ & 0.43 & $0.26[0.26,0.26]$ \\
\hline Tasmania & 84 & $0.00[0.00,0.00]$ & 0.22 & $0.42[0.42,0.42]$ & 0.09 & $0.17[0.17,0.17]$ \\
\hline Victoria & 1,308 & $0.00[0.00,0.00]$ & 3.72 & $0.67[0.67,0.67]$ & 1.49 & $0.27[0.27,0.27]$ \\
\hline Western Australia & 989 & $0.00[0.00,0.00]$ & 2.23 & $0.95[0.95,0.95]$ & 0.89 & $0.38[0.38,0.38]$ \\
\hline Australia & 5,074 & $0.00[0.00,0.00]$ & 16.12 & $0.72[0.72,0.72]$ & 6.45 & $0.29[0.29,0.29]$ \\
\hline
\end{tabular}

This article is protected by copyright. All rights reserved. 


\begin{tabular}{|c|c|c|c|c|c|c|}
\hline Tramadol & Number of packs & $\begin{array}{c}\text { Packs per person [95\% } \\
\text { Cls] }\end{array}$ & Crude utilisation kgs & $\begin{array}{c}\text { mg per person } \\
{[95 \% \mathrm{Cls}]}\end{array}$ & Total OME kg & OME mg per person [95\% Cls] \\
\hline Australian Capital Territory & 35,016 & $0.10[0.09,0.10]$ & 76.49 & $207.85[207.81,207.90]$ & 15.30 & $41.57[41.55,41.59]$ \\
\hline New South Wales & $1,048,197$ & $0.15[0.14,0.15]$ & $2,282.01$ & $316.13[316.12,316.15]$ & 456.40 & $63.23[63.22,63.23]$ \\
\hline Northern Ter & 25,115 & $0.11[0.11,0.11]$ & 50.64 & $218.95[218.89,219.01]$ & 10.13 & $43.79[43.76,43.82]$ \\
\hline Queensland & 845,533 & $0.19[0.19,0.19]$ & $1,864.52$ & $416.56[416.54,416.58]$ & 372.90 & $83.31[83.30,83.32]$ \\
\hline South Austra & 372,939 & $0.23[0.23,0.23]$ & 832.49 & $507.74[507.70,507.77]$ & 166.50 & $101.55[101.53,101.56]$ \\
\hline Tasmania & 168,339 & $0.33[0.33,0.33]$ & 373.57 & $730.37[730.30,730.44]$ & 74.71 & $146.07[146.04,146.11]$ \\
\hline Victoria & 894,178 & $0.16[0.16,0.16]$ & $1,824.46$ & $329.45[329.44,329.47]$ & 364.89 & $65.89[65.88,65.90]$ \\
\hline Western Australia & 613,642 & $0.26[0.26,0.26]$ & $1,277.14$ & $542.68[542.65,542.71]$ & 255.43 & $108.54[108.52,108.55]$ \\
\hline Australia & $4,002,959$ & $0.18[0.18,0.18]$ & $8,581.31$ & $384.19[384.18,384.20]$ & $1,716.26$ & $76.84[76.83,76.84]$ \\
\hline Dextropropoxyphene & Number of packs & $\begin{array}{c}\text { Packs per person [95\% } \\
\text { Cls] }\end{array}$ & Crude utilisation kgs & $\begin{array}{l}\text { mg per person } \\
{[95 \% \mathrm{Cls}]}\end{array}$ & Total OME kg & OME mg per person [95\% Cls] \\
\hline Australian Capital Territory & 10,536 & $0.03[0.03,0.03]$ & 6.89 & $18.67[18.65,18.68]$ & 0.69 & $1.87[1.86,1.87]$ \\
\hline New South Wales & 203,502 & $0.03[0.03,0.03]$ & 132.63 & $18.37[18.37,18.38]$ & 13.26 & $1.84[1.84,1.84]$ \\
\hline Northern Territory & 1,367 & $0.01[0.01,0.01]$ & 0.90 & $3.91[3.90,3.92]$ & 0.09 & $0.39[0.39,0.39]$ \\
\hline Queensland & 78,231 & $0.02[0.02,0.02]$ & 51.05 & $11.41[11.40,11.41]$ & 5.11 & $1.14[1.14,1.14]$ \\
\hline South Australia & 58,413 & $0.04[0.04,0.04]$ & 38.08 & $23.22[23.22,23.23]$ & 3.81 & $2.32[2.32,2.32]$ \\
\hline Tasmania & 7,168 & $0.01[0.01,0.01]$ & 4.74 & $9.26[9.25,9.27]$ & 0.47 & $0.93[0.92,0.93]$ \\
\hline Victoria & 77,558 & $0.01[0.01,0.01]$ & 50.57 & $9.13[9.13,9.13]$ & 5.06 & $0.91[0.91,0.91]$ \\
\hline Western Australia & 27,472 & $0.01[0.01,0.01]$ & 18.14 & $7.71[7.70,7.71]$ & 1.81 & $0.77[0.77,0.77]$ \\
\hline Australia & 464,247 & $0.02[0.02,0.02]$ & 302.98 & $13.56[13.56,13.57]$ & 30.30 & $1.36[1.36,1.36]$ \\
\hline
\end{tabular}

This article is protected by copyright. All rights reserved. 


\begin{tabular}{|c|c|c|c|c|c|c|}
\hline Over-the-counter codeine & Number of packs & $\begin{array}{c}\text { Packs per person }[95 \% \\
\text { Cls] }\end{array}$ & Crude utilisation kgs & $\begin{array}{c}\text { mg per person } \\
{[95 \% \mathrm{Cls}]}\end{array}$ & Total OME kg & OME mg per person [95\% Cls] \\
\hline Australian Capital Territory & 260,530 & $\begin{array}{c}0.71 \\
{[0.71,0.71]}\end{array}$ & 82.80 & $\begin{array}{c}225.01 \\
{[224.96,225.06]}\end{array}$ & 10.76 & $29.25[29.23,29.27]$ \\
\hline New South Wales & $5,167,482$ & $\begin{array}{c}0.72 \\
{[0.72,0.72]} \\
\end{array}$ & $1,669.15$ & $\begin{array}{c}231.23 \\
{[231.22,231.24]}\end{array}$ & 216.99 & $30.06[30.06,30.06]$ \\
\hline Northern Territory & 158,987 & $\begin{array}{c}0.69 \\
{[0.68,0.69]} \\
\end{array}$ & 49.51 & $\begin{array}{c}214.07 \\
{[214.01,214.13]} \\
\end{array}$ & 6.44 & $27.83[27.81,27.85]$ \\
\hline Queensland & $3,053,670$ & $\begin{array}{c}0.68 \\
{[0.68,0.68]}\end{array}$ & $1,007.84$ & $\begin{array}{c}225.17 \\
{[225.15,225.18]}\end{array}$ & 131.02 & $29.27[29.27,29.28]$ \\
\hline South Australia & $1,190,464$ & $\begin{array}{c}0.73 \\
{[0.72,0.73]} \\
\end{array}$ & 390.50 & $\begin{array}{c}238.17 \\
{[238.14,238.19]} \\
\end{array}$ & 50.76 & $30.96[30.95,30.97]$ \\
\hline Tasmania & 350,045 & $\begin{array}{c}0.68 \\
{[0.68,0.69]}\end{array}$ & 110.72 & $\begin{array}{c}216.48 \\
{[216.44,216.52]}\end{array}$ & 14.39 & $28.14[28.13,28.16]$ \\
\hline Victoria & $3,403,413$ & $\begin{array}{c}0.61 \\
{[0.61,0.62]}\end{array}$ & $1,063.37$ & $\begin{array}{c}192.02 \\
{[192.01,192.03]}\end{array}$ & 138.24 & $24.96[24.96,24.97]$ \\
\hline Western Australia & $1,905,617$ & $\begin{array}{c}0.81 \\
{[0.81,0.81]}\end{array}$ & 593.40 & $\begin{array}{c}252.15 \\
{[252.13,252.17]}\end{array}$ & 77.14 & $32.78[32.77,32.79]$ \\
\hline Australia & $15,490,207$ & $\begin{array}{c}0.69 \\
{[0.69,0.69]}\end{array}$ & $4,967.30$ & $\begin{array}{c}222.39 \\
{[222.38,222.39]}\end{array}$ & 645.75 & $28.91[28.91,28.91]$ \\
\hline
\end{tabular}

This article is protected by copyright. All rights reserved. 


\section{CONFUCTOF INTIEESTDISCLOSURE}

The Editors of Pha macoepidemiology and Drug Safety recognize that most studies in pharmacoepidemiology cost money and thus pose a potential conflic t of interest. As a conflict of interest may affect the assessment or jud gment of an author, we ask that all a uthors (not just the Corresponding Author) complete the following form.

For Co-authors: Please complete questions 4-10. Completed forms should be saved, and emailed as an attachment to the Corresponding Author.

For Corresponding Authors: Please complete all questions. It is the responsibility of the Corresponding Author to submit completed forms on behalf of all co-authors via Manuscript Central at the point of manusc ript sub mission.

\section{Comesponding author only (Co-authors go to Question 4):}

POTENTIAL STUDY INTERPRETATION CONFLICTS

1. Some or all of the data that were used in this study were provided by a company with a vested interest in the product being studied.

No

$+2$

2. The sponsor of this project had the right of commenting but the authors retained the right to acc ept or reject comments or suggestions.

No

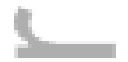

3. The sponsor of this project had the right of final editing and/or approval of the ma nusc ript submitted.

No

\section{Comesponding author and Co-authors:}

POTENTIAL FINANCIAL CONFUCTS

4. I, my spouse, or one of my dependent children is an employee of a company whose product is being studied.

No

5. I, my spouse, or one of my dependent children has signific a nt equity interest (> USD 10,000 ) in the company that owns the product being studied.

No 
6. In the past three years I have:

- been paid as a consultant (or in a similar capacity) by a company with a vested interest in the product being studied, on issues related to the product being studied; No

- been paid as a consultant (or in a similar capacity by a company with a vested interest in the product being studies, on issuesunrelated to the product being studied; No

- rec eived research or educ ational support from a company with a vested interest in the product(s) being studied.

No

$=$

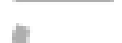

7. A company whose product is being studied has provided funding to support the work on this project.

No

If you have answered YES to any of the above questions, or if you have additional personal, commercial or academic conflic ts of interest, please draft a statement to publish with the article. e.g., AB hasbeen reimbursed by Safe Drug Ltd. for intemational conference attendance.

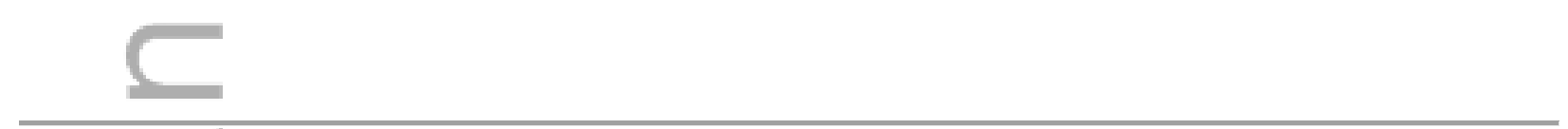

8. Manusc ript title (first six words a re suffic ient)

The extent and predictors of pharmaceutical opioid utilisatoin in community settings in Australia

9. Author's full name (a separate form must be sub mitted for each author)

Natasa Gisev

10. In checking this box, I confirm I have completed this form to the best of my knowledge. $\square$

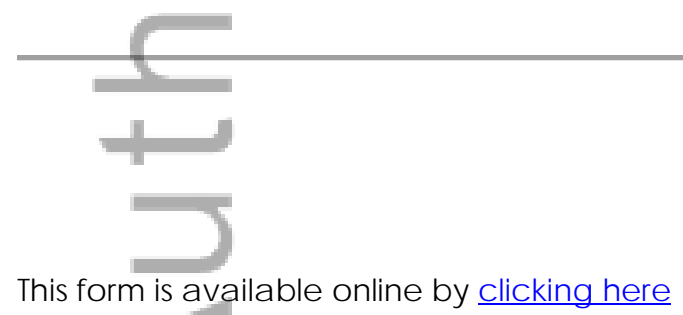




\section{CONFUCTOF INTIEESTDISCLOSURE}

The Editors of Pha macoepidemiology and Drug Safety recognize that most studies in pharmacoepidemiology cost money and thus pose a potential conflic t of interest. As a conflict of interest may affect the assessment or jud gment of an author, we ask that all a uthors (not just the Corresponding Author) complete the following form.

For Co-authors: Please complete questions 4-10. Completed forms should be saved, and emailed as an attachment to the Corresponding Author.

For Corresponding Authors: Please complete all questions. It is the responsibility of the Corresponding Author to submit completed forms on behalf of all co-authors via Manusc ript Central at the point of manusc ript sub mission.

\section{Comesponding author only (Co-authors go to Question 4):}

POTENTIAL STUDY INTERPRETATION CONFLICTS

1. Some or all of the data that were used in this study were provided by a company with a vested interest in the product being studied.

Yes

2. The sponsor of this project had the right of commenting but the authors retained the right to accept or reject comments or suggestions.

Yes

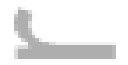

3. The sponsor of this project had the right of final editing and/or approval of the ma nusc ript submitted.

Yes

\section{Comesponding author and Co-authors:}

POTENTIALFINANCIAL CONFUCTS

4. I, my spouse, or one of my dependent children is an employee of a company whose product is being studied.

No

5. I, my spouse, or one of my dependent children has signific a nt equity interest (>USD 10,000) in the company that owns the product being studied.

No 
6. In the past three years I have:

- been paid as a consultant (or in a similar capacity) by a company with a vested interest in the product being studied, on issues related to the product being studied; No

- been paid as a consultant (or in a similar capacity by a company with a vested interest in the product being studies, on issuesunrelated to the product being studied; No

- rec eived research or educ ational support from a company with a vested interest in the product(s) being studied.

No

$=$

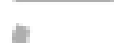

7. A company whose product is being studied has provided funding to support the work on this project.

Yes

If you have answered YES to any of the above questions, or if you have additional personal, commercial or academic conflic ts of interest, please draft a statement to publish with the article. e.g., AB hasbeen reimbursed by Safe Drug Ltd. for intemational conference attendance.

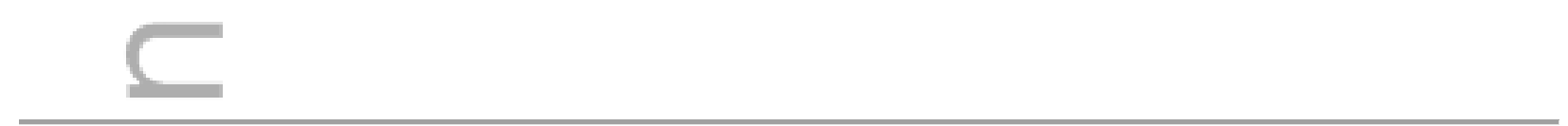

8. Manusc ript title (first six words a re sufficient)

The extent and predictors of pharmaceutical opioid utilisation in community settings in Australia

9. Author's full name (a separate form must be sub mitted for each author)

Ms Elena Cama

10. In checking this box, I confirm I have completed this form to the best of my knowledge. $\square$

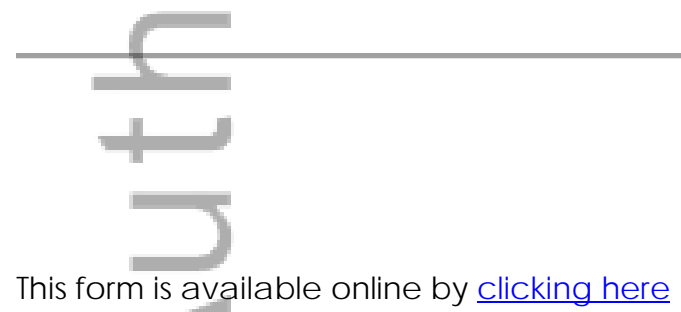




\section{CONFUCTOF INTIEESTDISCLOSURE}

The Editors of Pha macoepidemiology and Drug Safety recognize that most studies in pharmacoepidemiology cost money and thus pose a potential conflic t of interest. As a conflict of interest may affect the assessment or jud gment of an author, we ask that all a uthors (not just the Corresponding Author) complete the following form.

For Co-authors: Please complete questions 4-10. Completed forms should be saved, and emailed as an attachment to the Corresponding Author.

For Corresponding Authors: Please complete all questions. It is the responsibility of the Corresponding Author to submit completed forms on behalf of all co-authors via Manuscript Central at the point of manusc ript sub mission.

\section{Comesponding author only (Co-authors go to Question 4):}

POTENTIAL STUDY INTERPRETATION CONFLICTS

1. Some or all of the data that were used in this study were provided by a company with a vested interest in the product being studied.

No

$+2$

2. The sponsor of this project had the right of commenting but the authors retained the right to acc ept or reject comments or suggestions.

No

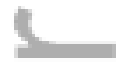

3. The sponsor of this project had the right of final editing and/or approval of the ma nusc ript submitted.

No

\section{Comesponding author and Co-authors:}

POTENTIAL FINANCIAL CONFUCTS

4. I, my spouse, or one of my dependent children is an employee of a company whose product is being studied.

No

5. I, my spouse, or one of my dependent children has signific a nt equity interest (> USD 10,000 ) in the company that owns the product being studied.

No 
6. In the past three years I have:

- been paid as a consultant (or in a similar capacity) by a company with a vested interest in the product being studied, on issues related to the product being studied; No

- been paid as a consultant (or in a similar capacity by a company with a vested interest in the product being studies, on issuesunrelated to the product being studied; No

- rec eived research or educ ational support from a company with a vested interest in the product(s) being studied.

Yes

In

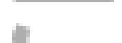

7. A company whose product is being studied has provided funding to support the work on this project.

Yes

If you have answered YES to any of the above questions, or if you have additional personal, commercial or academic conflic ts of interest, please draft a statement to publish with the article. e.g., AB hasbeen reimbursed by Safe Drug Ltd. for intemational conference attendance.

SN has been an investigator on untied educational grants from Reckitt-Benkiser, who have no involvement with or knowledge of this work. I have not personally received salary support through these projects.

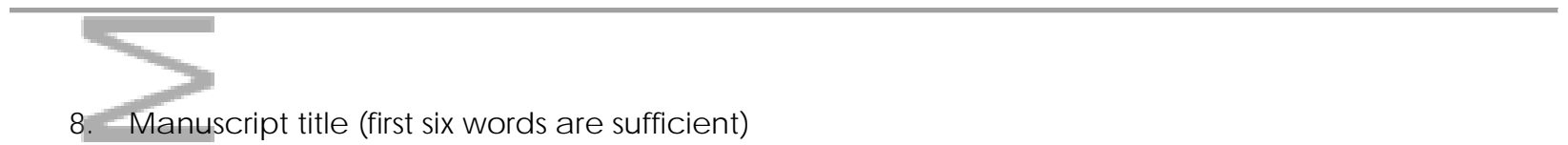

8. Manusc ript title (first six words are suffic ient)

9. Author's full name (a separate form must be submitted for each author)

Suzanne Nielsen

10. In checking this box, I confirm I have completed this form to the best of my knowledge. $\square$

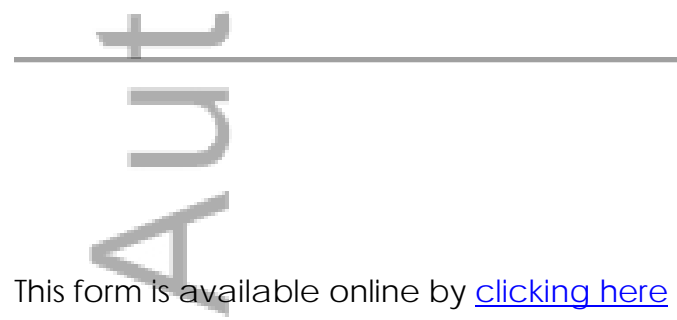




\section{CONFUCTOF INTIEESTDISCLOSURE}

The Editors of Pha macoepidemiology and Drug Safety recognize that most studies in pharmacoepidemiology cost money and thus pose a potential conflic t of interest. As a conflict of interest may affect the assessment or jud gment of an author, we ask that all a uthors (not just the Corresponding Author) complete the following form.

For Co-authors: Please complete questions 4-10. Completed forms should be saved, and emailed as an attachment to the Corresponding Author.

For Corresponding Authors: Please complete all questions. It is the responsibility of the Corresponding Author to submit completed forms on behalf of all co-authors via Manuscript Central at the point of manusc ript sub mission.

\section{Comesponding author only (Co-authors go to Question 4):}

POTENTIAL STUDY INTERPRETATION CONFLICTS

1. Some or all of the data that were used in this study were provided by a company with a vested interest in the product being studied.

No

$+2$

2. The sponsor of this project had the right of commenting but the authors retained the right to acc ept or reject comments or suggestions.

No

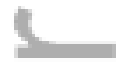

3. The sponsor of this project had the right of final editing and/or approval of the ma nusc ript submitted.

No

\section{Comesponding author and Co-authors:}

POTENTIAL FINANCIAL CONFUCTS

4. I, my spouse, or one of my dependent children is an employee of a company whose product is being studied.

No

5. I, my spouse, or one of my dependent children has signific a nt equity interest (> USD 10,000 ) in the company that owns the product being studied.

No 
6. In the past three years I have:

- been paid as a consultant (or in a similar capacity) by a company with a vested interest in the product being studied, on issues related to the product being studied; No

- been paid as a consultant (or in a similar capacity by a company with a vested interest in the product being studies, on issuesunrelated to the product being studied; No

- rec eived research or educ ational support from a company with a vested interest in the product(s) being studied.

Yes

$=$

(2.

7. A company whose product is being studied has provided funding to support the work on this project.

No

If you have answered YES to any of the above questions, or if you have additional personal, commercial or academic conflic ts of interest, please draft a statement to publish with the article. e.g., AB has been reimbursed by Safe Drug Ltd. for intemational conference attendance.

$B L$ has received untied educational grants from Reckitt Benckiser (for post-marketing surveillance of buprenorphine-naloxone tablets and film, development of an aberrant behaviour scale and a study of knowledge and uptake of opioid substitution therapy among chronic pain patients) and MundiPharma (post-marketing surveillance of a tamper-resistant formulation of oxycodone)

8. Ma nuscript title (first six words a re suffic ient)

The extent and predictors of pharmaceutical opioid utilisation in community settings in Australia

9. Author's full name (a separa te form must be submitted for each author)

\section{Briony Larance}

10. In check king this box, I confirm I have completed this form to the best of my knowledge. $\square$

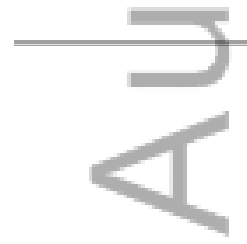

This form is a va ilable online by clicking here 


\section{CONFUCTOF INTIEESTDISCLOSURE}

The Editors of Pha macoepidemiology and Drug Safety recognize that most studies in pharmacoepidemiology cost money and thus pose a potential conflic t of interest. As a conflict of interest may affect the assessment or jud gment of an author, we ask that all a uthors (not just the Corresponding Author) complete the following form.

For Co-authors: Please complete questions 4-10. Completed forms should be saved, and emailed as an attachment to the Corresponding Author.

For Corresponding Authors: Please complete all questions. It is the responsibility of the Corresponding Author to submit completed forms on behalf of all co-authors via Manuscript Central at the point of manusc ript sub mission.

\section{Comesponding author only (Co-authors go to Question 4):}

POTENTIAL STUDY INTERPRETATION CONFLICTS

1. Some or all of the data that were used in this study were provided by a company with a vested interest in the product being studied.

Yes

2. The sponsor of this project had the right of commenting but the authors retained the right to accept or reject comments or suggestions.

Yes

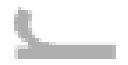

3. The sponsor of this project had the right of final editing and/or approval of the ma nusc ript submitted.

No

\section{Comesponding author and Co-authors:}

POTENTIAL FINANC IAL CONFUCTS

4. I, my spouse, or one of my dependent children is an employee of a company whose product is being studied.

No

5. I, my spouse, or one of my dependent children has signific a nt equity interest (>USD 10,000) in the company that owns the product being studied.

No 
6. In the past three years I have:

- been paid as a consultant (or in a similar capacity) by a company with a vested interest in the product being studied, on issues related to the product being studied; No

- been paid as a consultant (or in a similar capacity by a company with a vested interest in the product being studies, on issuesunrelated to the product being studied; No

- rec eived research or educ ational support from a company with a vested interest in the product(s) being studied.

Yes

In

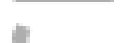

7. A company whose product is being studied has provided funding to support the work on this project.

No

If you have answered YES to any of the above questions, or if you have additional personal, commercial or academic conflic ts of interest, please draft a statement to publish with the article. e.g., AB hasbeen reimbursed by Safe Drug Ltd. for intemational conference attendance.

RB has received an untied educational grant from Reckitt Benckiser for a study examining opioid substitution therapy among chronic non-cancer pain patients. RB had received untied educational grant funding from Mundipharma for post-marketing surveillance of Reformulated OxyContin ${ }^{\circledR}$ in Australia.

8. Manusc ript title (first six words a re suffic ient)

The extent and predictors of pharmaceutical opioid utilisation in community settings in Australia 1

9. Author's full name (a separate form must be submitted for each author)

Raimondo Bruno

10. In chec king this box, I confim I have completed this form to the best of my knowledge. $\square$

This form is ava ilable online by clicking here 


\section{CONFUCTOF INTIEESTDISCLOSURE}

The Editors of Pha macoepidemiology and Drug Safety recognize that most studies in pharmacoepidemiology cost money and thus pose a potential conflic t of interest. As a conflict of interest may affect the assessment or jud gment of an author, we ask that all a uthors (not just the Corresponding Author) complete the following form.

For Co-authors: Please complete questions 4-10. Completed forms should be saved, and emailed as an attachment to the Corresponding Author.

For Corresponding Authors: Please complete all questions. It is the responsibility of the Corresponding Author to submit completed forms on behalf of all co-authors via Manuscript Central at the point of manusc ript sub mission.

\section{Comesponding author only (Co-authors go to Question 4):}

POTENTIAL STUDY INTERPRETATION CONFLICTS

1. Some or all of the data that were used in this study were provided by a company with a vested interest in the product being studied.

Yes

2. The sponsor of this project had the right of commenting but the authors retained the right to accept or reject comments or suggestions.

Yes

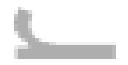

3. The sponsor of this project had the right of final editing and/or approval of the ma nusc ript submitted.

No

\section{Comesponding author and Co-authors:}

POTENTIAL FINANC IAL CONFUCTS

4. I, my spouse, or one of my dependent children is an employee of a company whose product is being studied.

No

5. I, my spouse, or one of my dependent children has signific a nt equity interest (>USD 10,000) in the company that owns the product being studied.

No 
6. In the past three years I have:

- been paid as a consultant (or in a similar capacity) by a company with a vested interest in the product being studied, on issues related to the product being studied; No

- been paid as a consultant (or in a similar capacity by a company with a vested interest in the product being studies, on issuesunrelated to the product being studied; No

- rec eived research or educ ational support from a company with a vested interest in the product(s) being studied.

Yes

$=$

(2)

7. A company whose product is being studied has provided funding to support the work on this project.

Yes

If you have answered YES to any of the above questions, or if you have additional personal, commercial or academic conflic ts of interest, please draft a statement to publish with the article. e.g., AB hasbeen reimbursed by Safe Drug Ltd. for intemational conference attendance.

I have been provided with untied educational grant funding from Mundipharma to conduct postmarketing surveillance of a new oxycodone formulation in Australia. The data reported here were provided by Mundipharma to inform that surveillance. That company had no role in the design, conduct, write up or decision to publish findings from that post marketing surveillance.

8. Ma nuscript title (first six words a re suffic ient)

The extent and predictors of pharmaceutical opioid utilisation

9. Author's full name (a separa te form must be submitted for each author)

Louisa Degenhardt

10. In chècking this box, I confirm I have completed this form to the best of my knowledge.

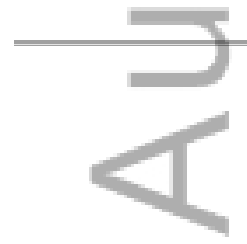

This form is a va ilable online by clicking here 


\section{University Library}

\section{- M M N E R VA A gateway to Melbourne's research publications}

Minerva Access is the Institutional Repository of The University of Melbourne

Author/s:

Degenhardt, L;Gisev, N;Cama, E;Nielsen, S;Larance, B;Bruno, R

Title:

The extent and correlates of community-based pharmaceutical opioid utilisation in Australia

Date:

2016-05-01

Citation:

Degenhardt, L., Gisev, N., Cama, E., Nielsen, S., Larance, B. \& Bruno, R. (2016).

The extent and correlates of community-based pharmaceutical opioid utilisation in Australia. PHARMACOEPIDEMIOLOGY AND DRUG SAFETY, 25 (5), pp.521-538. https:// doi.org/10.1002/pds.3931.

Persistent Link:

http://hdl.handle.net/11343/290846 